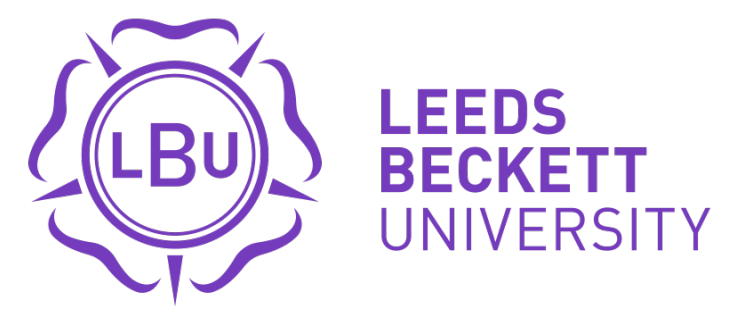

Citation:

Sharp, JG and Hemmings, B and Kay, R and Sharp, JC (2019) Academic boredom and the perceived course experiences of final year Education Studies students at university. Journal of Further and Higher Education, 43 (5). pp. 601-627. ISSN 0309-877X DOI: https://doi.org/10.1080/0309877X.2017.1386287

Link to Leeds Beckett Repository record:

https://eprints.leedsbeckett.ac.uk/id/eprint/4101/

Document Version:

Article (Accepted Version)

The aim of the Leeds Beckett Repository is to provide open access to our research, as required by funder policies and permitted by publishers and copyright law.

The Leeds Beckett repository holds a wide range of publications, each of which has been checked for copyright and the relevant embargo period has been applied by the Research Services team.

We operate on a standard take-down policy. If you are the author or publisher of an output and you would like it removed from the repository, please contact us and we will investigate on a case-by-case basis.

Each thesis in the repository has been cleared where necessary by the author for third party copyright. If you would like a thesis to be removed from the repository or believe there is an issue with copyright, please contact us on openaccess@leedsbeckett.ac.uk and we will investigate on a case-by-case basis. 


\title{
Academic boredom and the perceived course experiences of final year Education Studies students at university
}

\author{
John G. Sharp", Brian Hemmings ${ }^{2}$, Russell Kay ${ }^{2}$ and Jane C. Sharp ${ }^{1}$ \\ ${ }^{1}$ Carnegie School of Education \\ Leeds Beckett University \\ Headingley Campus \\ Leeds LS6 3QS \\ UK \\ ${ }^{2}$ Faculty of Education \\ Charles Sturt University \\ Wagga Wagga \\ NSW 2678 \\ Australia
}

Please direct all correspondence to the first author, Professor John G. Sharp

This article is protected until released for publication

(C) Sharp, Hemmings, Kay and Sharp - August, 2017 


\title{
Academic boredom and the perceived course experiences of final year Education Studies students at university
}

\begin{abstract}
This work explores the relationships between academic boredom and the perceived course experiences of 179 final year Education Studies students attending a single university in England. Adopting a mixed-methods design, with data collection employing a combination of questionnaires and individual research interviews, findings suggest that all participants exhibited some measurable disposition towards academic boredom with traditional lectures and work leading to the completion of assignments the main sites and triggers for the actual onset of academic boredom itself. Amid overwhelmingly encouraging responses from course expectations to course demands, reflecting the successful promotion of deep ways of working, as well as a clear sense of satisfaction with their teaching and learning environment overall, cluster analysis reveals the presence of five structurally related groups of students with profiles which help identify those typically more engaged and effective learners from others. Path analysis reveals a series of complex inter-connections with academic boredom emerging as a strong and direct predictor of surface ways and organised effort as well as contributing indirectly towards degree outcome as a whole. The implications for boredom mitigation are considered.
\end{abstract}

Keywords: academic boredom, teaching and learning, mixed-methods, cluster analysis, path analysis, higher education 


\section{Introduction and purpose}

As surprising as it might seem, students really do get bored at university. Despite the best of intentions, university does not always provide the personal, social and intellectual stimulation or challenge that many undergraduates need to keep them actively engaged (Schutz and Pekrun, 2007; Linnenbrink-Garcia and Pekrun, 2011). While the outward and more visible signs of academic boredom are usually clear, including drowsiness and yawning in class, heads resting in hands, bodies slouched in seats, vacant or distant stares and the distractions that come with ready access to electronic devices, the underlying consequences are perhaps more 'sinister' (Van Tilberg and Igou, 2012). At one level, of course, it might be assumed that academic boredom is nothing to be overly concerned about. Almost everyone experiences boredom at one time or another and students are certainly not immune. Academic boredom can, in fact, be a positive and creative experience providing opportunities for reflection for some (Vodanovich, 2003a; Goetz et al., 2010; Bench and Lench, 2013; Villavicencio and Bernardo, 2013; Mann, 2016; Elpidorou, 2017). It might even be simply shrugged off as a minor irritation by others. Increasingly associated with loneliness and withdrawal, anxiety and depression, irritability and agitation, drug and alcohol abuse, self-harm, over-eating, internet addiction and dropping out (Todman, 2003; Vodanovich, 2003b; Goldberg et al., 2011; Malkovsky et al., 2012; Moynihan et al., 2015; Skues et al., 2016; Respondek et al., 2017), however, academic boredom is a largely negative and disabling achievement-related emotion known to play a more critical role among students at university than previously thought (Pekrun and Stevens, 2010). With between $26 \%$ and $59 \%$ of students admitting to being frequently bored in lectures alone (Harris, 2000; Mann and Robinson, 2009; Tze et al., 2016), the cumulative effects of academic boredom are far from trivial and not to be underestimated (Pekrun et al., 2010).

With the study of achievement-related emotions including academic boredom gaining some traction but still relatively underdeveloped across the UK higher education sector as a whole (Loon and Bell, 2017), quantitative data from questionnaires and qualitative data from ten individual research interviews are combined here in a mixed-methods study which includes cluster and path analysis (Greene, 2007; Creswell and PlanoClark, 2011). From within Control-Value Theory (Pekrun, 2000, 2006), where this work 
is grounded, and by way of a working hypothesis, it would not be unreasonable to presuppose or to anticipate that those students more prone to academic boredom than others might also perceive their encounters with the teaching and learning environment less favourably, adopt less effective ways of working and consequently do less well in terms of overall academic performance and achievement. The purpose of this work, then, is to explore the relationships between these and other related variables together for the first time and to consider the implications arising from findings, thereby providing a valuable contribution to the field.

\section{Review of literature}

\section{Academic boredom and the BPS-UKHE}

Boredom, as a 'universal' concept, has attracted cultural and philosophical interest for some considerable time (Healy, 1986; Spacks, 1995; Svendsen, 2005; Toohey, 2012; Haladyn, 2015). Leading up to and throughout the 1980s, however, psychologists in particular began to identify boredom more formally as a highly elusive and situated but aversive state, the perceived experience of boredom by any individual at any given moment in time, arising in response to task situations in which the pattern of sensory stimulation was either constant and familiar or highly repetitive and monotonous (Lewinsky, 1943; Greenson, 1953; Heron, 1957; O'Connor, 1967; Russell, 1980; Smith, 1981; O'Hanlon, 1981; Perkins and Hill, 1985). As a trait, the recurring propensity or habitual disposition towards getting bored, boredom was also deemed measurable as a unitary construct using the Boredom Proneness Scale or BPS (Farmer and Sundberg, 1986). Into the 1990s and beyond, boredom was perhaps described more precisely as an indicator of 'relatively low arousal and dissatisfaction ... attributed to an inadequately stimulating situation' (Mikulas and Vodanovich, 1993) and an unpleasantness emanating from 'a pervasive lack of interest in and difficulty concentrating on [any] current activity' (Fisher, 1993). Associated with the wide range of human conditions and pathologies indicated earlier, boredom's 'universality', its complexly inter-twinned cognitive, affective, motivational, physiological and expressive dimensions, and the misattribution of all manner of things to boredom and vice versa, rendered it notoriously difficult to isolate and study in detail. Somewhat similarly, and throughout that time, theories of boredom traditionally fell into four main 
camps, arousal-related, attention-related, psychodynamic and existential, rendering it open to criticism as being shaped by different disciplinary inclinations, theoretical impulses and methodological affiliations.

Academic boredom, the boredom experienced by students at university, and sufficiently different from other forms of boredom (e.g. existential, work-related, freetime, leisure-related, cultural and sexual), has a relatively recent history (VogelWalcutt et al., 2012). An equally recent trans-theoretical perspective evolving from academic boredom's hybridity in real-life educational settings and the nature of student attribution and expectancy has also been proposed. From within Control-Value Theory or C-VT, academic boredom is defined as 'an intense, if often brief, psychophysiological response to a supposedly meaningful educational event'. In essence, C-VT predicts the outcome direction or 'valence' (positive or negative) as well as the nature of activation (enabling or disabling) associated with the completion of academic tasks or activities (Pekrun, 2000, 2006). Usefully summarised by Ruthig et al. (2008), for example, students commonly anticipate success or failure depending on what they attribute to the successes or failures of the past and the extent to which they can exert any control or influence over those factors considered responsible. Relative to the actual benefit of doing so, students who believe that little control is possible, and unable or unwilling to overcome the impeding effects of academic boredom, are more likely to exhibit lower levels of commitment towards their academic goals, thereby lowering their performance prospects and outcomes. Similarly, and according to Tze et al (2016), the same also applies during instruction. In lectures, for example, if the material being presented is considered particularly challenging or demanding then the perceived value in learning it, no matter how important, may be diminished. The same is also true if the material being presented is insufficiently challenging or considered of little relevance. In both situations, students may become 'state-oriented' rather than 'goal-oriented' with an accompanying sense of 'disordered agency' (Eastwood et al., 2012). Within this framework, psychological studies of academic boredom involving students from Germany, Canada, the United States and China have since documented the cultural, contextual, disciplinary and individual differences in how academic boredom is experienced and accommodated (Acee et al., 2010; Pekrun et al., 2002, 2009, 2010, 2011, 2014; Tze et al., 2013, 2014, 2016; Goetz et al., 2014; Garn et al., 2017). Through the work led by Pekrun in particular, students are known 
to experience a rich diversity of emotions at university (e.g. enjoyment, hope, pride, relief, anger, anxiety, shame, hopelessness), with academic boredom leading to a reduction in motivation and effort, the adoption of more superficial and less flexible learning strategies impeding higher order thinking and problem-solving, distraction and the redirection of cognitive resources, the inability to self-regulate and plan, monitor and evaluate learning and poor meta-cognitive awareness. As a result, academic boredom not only has an adverse effect on performance, the two appear reciprocally related and mutually reinforcing. From experience sampling in vivo, Goetz et al (2014) have also produced a typology of states and forms including 'indifferent' (the least unpleasant), 'calibrating' (individuals could but choose not to react), 'searching' (individuals respond by looking for alternative stimuli), 'apathetic' (debilitating, individuals unable to respond) and 'reactant' (frustration or disruptive behaviours).

In the UK, academic boredom was first described by Mann and Robinson (2009) with other work, including the development of an academic boredom survey instrument and BPS-UKHE questionnaire, now beginning to emerge (Authors, 2017a,b). Alongside other methodological advances in the field (Vodanovich and Watt, 2016), the academic boredom survey instrument and BPS-UKHE questionnaire adopted here provide a more situated means with which to explore academic boredom's trait and state qualities together. Following the lead of Mann and Robinson (2009), the academic boredom survey instrument provides relevant information about how much time specific methods of course delivery respondents find interesting or engaging, why some methods are favoured over others and what coping strategies are adopted as a result. Despite remaining the only full-scale measure of an individual's propensity or habitual disposition towards getting bored, and still very much in use today, our decision to modify and adapt the original Farmer and Sundberg (1986) Boredom Proneness Scale or BPS for use in higher education was determined largely as a result of its age, the currency of its items and our concern over importing an instrument developed for more general use in a different cultural context (Authors, 2016).

Perceived course experiences and the SETLQ 
In an almost parallel evolution to that of academic boredom, the systematic study of perceived course experiences among students at university is widely attributed to the work of Entwistle and Ramsden (1983) with later contributions from others (e.g. Prosser and Trigwell, 1999). Ramsden and Entwistle's early influence over the field continued with publication of the Course Experience Questionnaire or CEQ developed for use with undergraduates in Australia (Ramsden, 1991) and the Experiences of Teaching and Learning Questionnaire or ETLQ developed for use with undergraduates in the UK (Entwistle et al., 2002). The ETLQ, together with its shortened derivative, the multipurpose SETLQ adopted here, came to prominence in the influential Enhancing Teaching-Learning Environments in Undergraduate Courses Project or ETLP intended to inform the quality of university teaching and course provision as well as to support academic staff in their increasingly diverse roles (Entwistle et al., 2002; Hounsell and Entwistle, 2005; see also Parpala et al., 2013 and Richardson, 2014).

Despite the inherent shortcomings of relying on questionnaire surveys alone (Richardson, 2004, 2005), variations of the CEQ and ETLQ have featured prominently in more recent studies undertaken in Australia, Spain, China and The Netherlands (Lizzio et al., 2002; Zhang, 2003; Kember, 2004; Nijhuis et al., 2008; Román et al., 2008), with particular interest emerging from Norway (Swanberg and Martinsen, 2010; Diseth, 2002, 2007, 2013) and Finland (Lindblom-Ylänne et al., 2006; Ruohoniemi and Lindblom-Ylänne, 2009; Parpala et al., 2010; Haarala-Muhonen et al., 2011; Rytkönen et al., 2012; Hailikari et al., 2016). While also highlighting many of the cultural, contextual, disciplinary and individual differences involved, student encounters with the teaching and learning environment and how their course experiences are perceived are frequently reported as of more importance than the purposes intended by lecturers, influencing certain ways of working over others rather than vice versa and impacting upon overall academic performance and achievement. While no unifying or overarching theoretical perspective has ever been established (C-VT does offer some potential worthy of further investigation), the heuristic model and conceptual framework of learning influences provided by Entwistle (2008, 2009), usefully assimilating the notion of constructive alignment most recently revised by Biggs and Tang (2011), offers considerable insight and helps visualise the complex inter-dependencies involved (Figure 1). 


\section{[Insert Figure 1 as close to here as possible.]}

Perhaps not surprisingly, given its recent emergence onto the international stage, only three studies have so far incorporated achievement-related emotions like academic boredom into a broader research frame despite the somewhat obvious benefits of doing so (Illeris, 2003). The first of these, with first year biology students at a university in Australia (Trigwell et al., 2012), was entirely quantitative in nature; the other two were from an earlier phase of this work and of mixed-methods design (Authors, 2017b, submitted). These considered academic boredom alongside participants' approaches to studying and learning and learning reporting positive correlations with more surfacedriven strategies and the negative prediction of performance.

\section{Methodology}

Research design, sampling and ethics

The work presented here completes our ongoing and sequential mixed-methods research project intended to explore the nature and influence of academic boredom on the course experiences of three internally consistent cohorts of final year Education Studies students attending a single university in England. The Education Studies programme at this particular institution was a popular choice among students, offering various exit routes into initial teacher training upon completion. Sampling was both purposive and convenient, with due consideration directed towards the overall aims of the project as a whole, its methodology and the elusive and transient nature of academic boredom described earlier (Gorard, 2004; Johnson et al., 2007; Cohen et al., 2011). Though by no means unique, the involvement of final-year students is, nevertheless, uncommon, providing rare insight into the prevalence of academic boredom and its effects among individuals looking to undertake further study and training to become teachers. While ethical approval was obtained in accordance with institutional policy as guided by the British Educational Research Association (BERA, 2011), student participation remained entirely voluntary with informed consent throughout. 
The quantitative data for this study came from four sources:

- an 'about you' questionnaire requesting demographic details of participants themselves;

- the academic boredom survey instrument and BPS-UKHE questionnaire introduced earlier (18-items, one scale, three subscales - tedium, concentration, time);

- the Shortened Experiences of Teaching and Learning Questionnaire or SETLQ also introduced earlier (60-items, four scales - course expectations, ways of working, perceived course experiences, perceived course demands, sixteen subscales);

- final year degree outcomes of participants as percentages and degree classifications from student records.

Because of the project's focus on academic boredom, 380 academic boredom survey instruments with the BPS-UKHE questionnaire were distributed first during whole-year lectures given as part of an educational research methods module. 380 'about you' and SETLQ questionnaires were distributed afterwards over several weeks during group-seminars. Overall, 309 survey instruments and BPS-UKHE questionnaires, 250 'about you' and 208 SETLQ questionnaires were completed and subsequently returned (response rates of $81.3 \%, 65.8 \%$ and $54.7 \%$ respectively). This resulted in 179 complete data sets for which degree outcomes could also be matched (see limitations). During interrogation of the quantitative data, all statistical procedures, including analysis of variance, correlation, cluster and path analysis, were carried out using SPSS ${ }^{1}$ and AMOS$^{2}$ (Byrne, 2013; Field, 2013; Ho, 2014). Bonferroni adjustments and effect sizes are reported where appropriate.

Unlike the BPS-UKHE which was developed for purpose, the SETLQ questionnaire was further reduced and modified to focus on course rather than modular detail and final year rather than an interim year of study and therefore subjected to Principal Component Analysis or PCA to compare construct validity and internal reliability with 
the published original (Entwistle et al., 2002). Replication of the overall factor structure at subscale level revealed only minor variation, the overall solution accounting for $54.3 \%$ of the variance observed (PCA parameters ${ }^{1}$ : oblique rotation; $\mathrm{KMO}=0.807$; Bartlett's $\kappa^{2}=734.9, \mathrm{df}=120, \mathrm{p}<.001$; eigenvalues $>1$ ). Despite occasionally elevated skewness and kurtosis values, all scales and subscales were considered normally distributed. Further details associated with both questionnaires are presented as shown (Appendices 1 and 2).

\section{Qualitative data collection and analysis}

The qualitative data for this study came from ten research interviews with respondents identified and selected by availability and a standard deviation split in BPS-UKHE scores (mean +/- 1 standard deviation). This was intended to maximise differentiation in response, to provide a richer source of information with which to complement and illuminate quantitative findings and to better understand variable relationships by integrating the quantitative and qualitative methods into a more coherent whole (Tashakkori and Teddlie, 1998). These included:

- Lisa, Laura, Liam and Luke (two female and two male students with particularly low BPS-UKHE scores - pseudonyms reflecting a relatively low propensity towards academic boredom);

- Hannah, Heather, Harriet, Holly, Harry and Howie (four female and two male students with particularly high BPS-UKHE scores - pseudonyms reflecting a relatively high propensity towards academic boredom).

All interviews, lasting up to one hour in duration, were semi-structured and conducted in a relaxed manner in private to ensure a free and 'interactional exchange of dialogue' and flexibility in direction and response (Powney and Watts, 1987; Fontana and Frey, 2000; Mason, 2000; Schostack, 2006). Interview questions themselves were guided by the research literature, the main characteristics of academic boredom and those areas of teaching and learning probed by the SETLQ. Examples are presented as follows: 
- As you approach the end of your degree, can you remember what it was that initially attracted you to this course in particular?

- If you ever find yourself in a boring lecture/seminar/tutorial what do you tend to do as a result?

- How do you go about studying for, preparing for and writing your assignments/what do you tend to do with the feedback you receive/how does it help when looking ahead to the next?

- Do you ever find writing your assignments interesting/boring/how does that affect your work?

- Overall, do you find your course particularly easy/demanding/are you able to devote as much time to your academic work as you would like?

Audio-recordings were transcribed independently to help minimise researcher bias and subsequently shared and analysed manually by way of content analysis (Miles et al., 2014). First order coding was pragmatic, eclectic and emotion-oriented in nature (e.g. site, trigger, response, attribution, motivation, demand) and used primarily to identify second order categories and themes with quotations favoured over words and phrases as the basic units of analysis. The similarities and differences in responses between those individuals in the high and low BPS-UKHE groups could then be compared (Saldaña, 2013).

\section{Presentation of findings}

Findings are reported here in two parts. The first begins with an account of respondent characteristics, academic boredom, course expectations and ways of working, concluding with a cluster analysis incorporating final year degree outcome. The second considers academic boredom alongside the perceived experiences of teaching and learning including course demands and concludes with a path analysis. Qualitative findings from the research interviews are incorporated throughout.

Respondent characteristics 
Demographic information from the 'about you' questionnaire is presented as shown (Table 1). 41 (22.9\%) respondents were male and 138 (77.1\%) were female, a proportion typical of the course as a whole. While 136 (76.0\%) started university soon after school, the overall range of ages presented resulted in an estimated sample mean of 24.4 years at the time of study. Most respondents were the first members of their immediate families to go to university (119 or 66.5\%) and most were also from 'manual' occupational backgrounds (102 or 57.0\%). Attendance was largely described as excellent (120 or $67.0 \%$ ) or good (53 or $29.6 \%$ ), the amount of time devoted to selfstudy averaged 14.4 hours per week and 106 (59.2\%) respondents worked in parttime employment.

\section{[Insert Table 1 as close to here as possible]}

\section{Academic boredom}

Academic trait boredom, the recurring propensity or habitual disposition of students towards getting bored at university, was measured with reference to the statements contained within the BPS-UKHE questionnaire. Individual scores varied from as low as 20 (minimum possible 18) to a high of 74 (maximum possible 90) with a mean of 43.3 (standard deviation=9.57). Reduced to its original 5-point scale to match other questionnaire variables, individual scores varied from 1.1 (least prone) to 4.1 (most prone) with a mean of 2.40 (standard deviation=0.532). In order of decreasing mean value across the questionnaire's three subscales, respondents appeared marginally more susceptible to academic boredom on the tedium subscale (SD=standard deviation):

- tedium - monotony, repetition, confinement, low arousal (mean=2.49, $\mathrm{SD}=0.614)$;

- concentration - lack of focus, attention deficit, need for external stimulation (mean=2.42, SD=0.630);

- time - perceived as 'slowing down' or dragging by, time management (productive use), lack of interest (mean=2.26, SD=0.579). 
By way of example, and in terms of tedium alone, 107 (59.8\%) respondents found many of the things they had to do at university monotonous and repetitive at least occasionally if not more frequently (the highest scoring item overall). Similarly, 77 (43.0\%) found themselves trapped having to do meaningless things and $44(24.6 \%)$ considered almost everything about university particularly tiresome (the lowest scoring item overall). 17 (9.5\%) respondents exhibited relatively little propensity towards academic boredom at all (e.g. scores less than 2.0 across all three subscales) and only $2(1.1 \%)$ appeared particularly prone in the extreme (e.g. scores greater than 4.0 across all three subscales). In terms of the actual onset of academic boredom itself, traditional lectures were identified as the most common sites and triggers (see also later):

'A lecture should leave you asking questions of what you've been hearing, been listening to, and then want to go and find out something else about it ... Some of the best lectures l've had here have been really inspirational ... on the flip side of that, I've been in lectures that have just been dull as ditchwater.' (Luke)

The impact of lecture boredom on concentration, together with the strategies employed to help cope, was particularly revealing:

II don't think lectures take me out of my comfort zone but sometimes I go out of my listening zone ... I think that's when I get bored, if they're just repeating something I could have done at home, I just think "why am I here?" ... if you can see other people are bored, I get bored, like when I see other people are just on their phones or Facebook ... they're just not listening ... So it's not that I get bored a lot ... I just lose my concentration.' (Lisa)

I'm not taking anything in when I'm getting bored ... I doodle or clock watch ... or switch off ... it stops me falling asleep ... and then it's hard to get back into it again ... so I'm sort of walking out knowing the same as what I did when I walked in ... It sort of makes me feel like it's my fault, but if it doesn't interest me I get bored, there's nothing I can do.' (Heather)

The adverse effects of lecture boredom were notably greater amongst those interviewed with higher BPS-UKHE scores than others as anticipated.

Course expectations 
From the SETLQ, course expectations received overwhelmingly positive scores reflecting particularly high levels of motivation. In order of decreasing mean value across the questionnaire's four subscales, outcomes are presented as follows:

- intrinsic value (mean $=4.30, \mathrm{SD}=0.479)$;

- career (mean=4.22, $\mathrm{SD}=0.915)$;

- personal and social (mean=4.05, $\mathrm{SD}=0.789$ );

- lack of purpose (mean=1.81, SD=1.059).

By way of example, $172(96.1 \%)$ respondents 'agreed' that the things they would learn on their course would help them to develop as people and broaden their horizons (the highest scoring item overall), $147(82.1 \%)$ that they needed a degree in order to get a job in teaching (the most common exit route via a postgraduate qualification) and 131 $(73.2 \%)$ that university provided opportunities for an active social life including sport. At interview, an integration of views was common:

II was the first person to come to uni' out of my family ... I think I wanted to prove to myself that I could do this because I was the first one ... I also wanted to teach and make new friends.' (Lisa)

Independence, a bit of freedom ... Because I knew I wanted to be a teacher, always have done, and had to have a degree basically ... that's what keeps me going.' (Holly)

'Well, definitely the social aspects ... to live in halls ... new interests ... just life experience ... it's a whole new chapter in the book isn't it.' (Howie)

In terms of lack of purpose, only $17(9.5 \%)$ wondered why they went to university in the first place (the lowest scoring item overall).

\section{Ways of working}

From the SETLQ, ways of working are considered in terms of the broad approaches students adopt when studying and learning. These are identified here as deep (the intention to construct meaning and understanding for themselves), organised effort (the intention to maximise the deployment of personal resources to systematically support progression) and surface (the intention to cope with immediate task demands 
and other requirements at face value which may or may not make any sense). In order of decreasing mean value across the questionnaire's three subscales, overall scores were broadly typical of what might be expected of final year undergraduates committed to their course, with organised effort and deep ways of working scoring more highly than surface:

- $\quad$ organised effort (mean=3.70, $\mathrm{SD}=0.766)$;

- $\quad \operatorname{deep}($ mean=3.59, SD=0.407);

- $\quad$ surface $($ mean=2.76, $\mathrm{SD}=0.641)$.

By way of example, 153 (85.5\%) respondents 'agreed' to generally putting a lot of effort into their studies (the highest scoring item overall), slightly fewer (130 or $72.6 \%$ ) admitted to considering evidence carefully when reaching their own conclusions, while only $23(12.9 \%)$ suggested that they had simply been going through the motions of studying without really seeing where they were going at all (the lowest scoring item overall). At interview, ways of working produced contrasting accounts, especially during the preparation and completion of assignments:

'Generally, I get a big box full of reading. Then I'll go through it highlighting the bits I think are good and then disregard everything else ... I tend to get as much as I can then try and tie the themes together so I can synthesise it ... structure the argument basically ... I like to make sure ... it's coherent ... then I'll start ... I can add bits when I need or take bits away just to balance things.' (Luke: strong in organised effort and the adoption of deep approaches to learning)

'I think I don't allow myself enough time to probably look at it with fresh eyes and I think that's a downfall that l've come to realise probably a bit too late ... I think I skim through [books and articles] to look for ideas ... I think I get to a position where I know I need to do it ... so I cram ... probably, if I'm being honest with myself ... I find academic work hard to read sometimes and I get distracted.' (Hannah: weak in organised effort with more surface-oriented learning)

For at least one interviewee, completing assignments was simply a chore, drawing attention to their completion as additional sites and triggers for the actual onset of academic boredom itself: 
'Boring ... I put them off as long as I can 'cause ... it's just work and no one likes doing work ... I think there comes a time when you're just like, "oh, as long as it doesn't fail it's okay" ... I just keep reading around [from books], I gather all my quotes, write them down as well ... I write my assignments around my quotes.' (Harry)

Assignment boredom could, however, be strongly influenced by choice and having the freedom over what to do and how to do it. With their final year and extended research projects, for example, those more prone to academic boredom than others felt equally productive and creative having designed and undertaken their work to completion largely independently (see also later).

\section{Cluster analysis and final year degree outcome}

BPS-UKHE scores correlated moderately and negatively with intrinsic value, deep ways of working and organised effort as anticipated (e.g. organised effort $r=-.527$, $\mathrm{p}<.001)$. BPS-UKHE scores correlated moderately but positively with lack of purpose and surface ways of working also as anticipated (e.g. surface $r=.586, p<.001$ ). A negative correlation was also observed between BPS-UKHE scores and hours of selfstudy. A full table of outcomes is presented as shown (Table 2).

\section{[Insert Table 2 as close to here as possible]}

With both academic trait boredom and ways of working correlated as indicated, and known from within the research literature to exert influence over academic achievement and performance, these were entered into a hierarchical cluster analysis of data using Ward's method involving the standardisation of variables to z-scores to a common scale (with a mean of zero and a standard deviation of one). Attempts to include course expectations proved inconclusive. Five clusters (C1-C5) in which responses could be grouped according to similar structural relations were identified and summarised as follows:

- C1: 12 male and 48 female respondents (20.0\% and $80.0 \%$ respectively). Typically below average BPS-UKHE and surface scores, above average deep and organised effort scores. Measurably the least prone to academic boredom. 
Individuals most likely to be well organised, making the most effective use of time, and purposeful in directing effort towards meaningful learning and understanding.

- C2: 11 male and 36 female respondents (23.4\% and $76.6 \%$ respectively). Wide ranging but broadly average BPS-UKHE and deep scores, wide ranging but slightly depressed organised effort scores, below average surface scores.

- C3: 6 male and 32 female respondents (15.8\% and 84.2\% respectively). Typically above average BPS-UKHE and surface scores (tightly arranged), below average deep and organised effort scores. Propensity towards academic boredom and more surface ways of working over others becoming dominant.

- C4: 4 male and 15 female respondents (21.1\% and $78.9 \%$ respectively). A somewhat discordant cluster breaking with trend. Well above average BPSUKHE and surface scores presented alongside above average deep and organised effort scores. Suggests reasonably well organised and eclectic learners adapting to circumstances regardless of propensity towards boredom.

- C5: 8 male and 7 female respondents (53.3\% and $46.7 \%$ respectively). Male representation disproportionately high relative to other clusters and the sample as a whole. Well above average BPS-UKHE and surface scores, well below average deep and organised effort scores. Measurably the most prone to academic boredom and most likely to display the characteristics of less engaged and less effective learners.

The differences between individual variables across clusters were significant in all cases (e.g. academic boredom ANOVA F=65.351, $d f=4,174 p<.001 ; \eta^{2}=.600 ;$ greatest contrast between $\mathrm{C} 1$ and $\mathrm{C} 5 \mathrm{r}=.832$ ). Full details of the cluster profiles, most easily visualised as box and whisker plots, are presented as shown (Figure 2). Cluster characteristics become further enhanced and supported when annotated with demographic background and other information (e.g. C1: attendance $90.0 \%$ excellent, 17.9 hours of self-study on average per week; C5: attendance $40.0 \%$ excellent, 6.9 hours of self-study on average per week). At an even finer level of detail, and of the 17 respondents amotivated and lacking in purpose mentioned earlier, only 1 was located in $\mathrm{C} 1$ (1.7\% of that cluster) while 8 were located in C5 (55.3\% of that cluster). 
In terms of final year degree outcome, marks among all respondents ranged from $43 \%$ to $80 \%$ with a mean of $60.6 \%$ (SD=6.63\%). These were also typical of the course as a whole. As determined by the degree regulations of the institution at the time, these translated into 24 first class awards (13.4\%), 87 upper second class awards or 2:1s (48.6\%), 58 lower second class awards or 2:2s (32.4\%) and 10 third class awards (5.6\%). Importantly, final year degree marks correlated moderately and negatively with academic trait boredom and surface scores and weakly but positively with deep scores and organised effort (Table 2). Across the clusters, average marks were also observed to decrease systematically from C1 $(63.2 \%)$ to C5 (56.7\%), a small but significant 6.5 percentage point difference (ANOVA $F=7.508, d f=4,174 \quad p<.001$; $\eta^{2}=.147$; greatest contrast between $C 1$ and $\left.C 5 r=.461\right)$. A significant outcome was also observed in degree classification $\left(\kappa^{2}=33.342, d f=4, p<.001 ; V=0.432\right)$ with a corresponding decrease in 'good' degrees awarded (Figure 2).

\section{[Insert Figure 2 as close to here as possible.]}

\section{Perceived experiences of teaching and learning}

From the SETLQ, the majority of respondents appeared largely satisfied with almost all aspects of the course investigated. Outcomes are summarised in order of decreasing mean value across the questionnaire's seven teaching and learning subscales as follows:

- critical thinking (mean $=4.11, \mathrm{SD}=0.624)$;

- staff and student support ( $m e a n=4.02, \mathrm{SD}=0.530$ );

- interest and enjoyment (mean=3.99, $\mathrm{SD}=0.702$ );

- teaching for understanding (mean $=3.85, \mathrm{SD}=0.558$ );

- aims and congruence (mean=3.84, $\mathrm{SD}=0.567$ );

- set work and feedback (mean=3.83, $\mathrm{SD}=0.612$ );

- choice allowed (mean=3.44, SD=0.558). 
By way of example, $168(93.9 \%)$ respondents 'agreed' that having to think critically about the topics studied was essential in order to do well (the highest scoring item overall). This was also reflected at interview:

I'm always ... synthesising, bringing ideas together from other people. I always have a thought spark off in my head ... and then I'll write that down, explain it, analyse it ... I want people to think, "oh, yeah, that's really interesting, I wonder what he means by that" ... wanting to make my work really thought provoking ... when I look at journal papers, I have to read them four times sometimes ... to understand it.' (Liam)

By way of contrast, however, and as alluded to earlier, only 98 (54.7\%) 'agreed' that they were given a good deal of choice over what to focus on as they went about learning (the lowest scoring item overall). At interview, however, and particularly with assignments, this highlighted a conflict of interest and worrying sense of self-fulfilment:

'[Without a focus] I worry I'm not on the right lines. I just like to know what l've got to do, l've got an aim, I've got a goal, I can work from that ... l'm like "I don't know where to start with this" ... and it seems like more work is set in front of me ... I start off reading the assignment brief in detail ... the word limit ... what's expected of me, the grade boundary I aim for, the key features used ... I do a plan. I look at further reading, lecture notes, I slot it into the sections what l've read and how it fits and then write up.' (Harriet)

\section{[Insert Table 3 as close to here as possible]}

Across all five clusters, scores decreased systematically from $\mathrm{C} 1$ to $\mathrm{C} 5$ in all instances, but only significantly so in 'interest and enjoyment', 'teaching for understanding', 'aims and congruence' and 'set work and feedback'. Because of its scope as a scale, additional detail is presented at an item level as shown (Table 3). In 'interest and enjoyment', which exhibited the greatest difference in scores (ANOVA $F=13.811$, $\mathrm{df}=4,174 \mathrm{p}<.001 ; \eta^{2}=.241$; greatest contrast between $\mathrm{C} 1$ and $\left.\mathrm{C} 5 \mathrm{r}=.655\right), 147(82.1 \%)$ respondents 'agreed' that most of what they learned on the course was really interesting. While 58 of those were located in $\mathrm{C} 1$ ( $96.7 \%$ of that cluster), only 5 were located in C5 (33.3\% of that cluster). Reasons and justification often varied, reflecting sometimes very different opinions: 
I've really enjoyed the course. I know we get a few people who don't think too much to it, or moan about It ... I'm not the kind of person that really ever whinges about anything, I just get on with it.' (Liam)

'If I'm not interested I'll be like "please get this module over and done with, I've had enough" ... I know there's going to be people out there who've got better grades than me but I might have a better experience than them, so it's important but it's not the sole importance in life.' (Howie)

Similarly, and with assignment feedback and how it was received and used, comments focused mainly on its shortcomings in particular:

II don't really look at what they said was good, I look at what they said I need to do better on ... but the feedback doesn't make a difference if you keep getting the same feedback over and over again' (Lisa)

'I do look back on previous assignments to see what feedback l've had ... I just try to build on what l've done before ... Some of the feedback has been vague.' (Luke)

I'm bad at focusing on the negative parts ... and not looking at what is positive about it ... Sometimes, with feedback previously l've had, I've felt that it's not helped progress, but I suppose that depends on the marker.' (Hannah)

'Yes and no, it depends. Sometimes you can't read the writing ... then you've got to run around to find someone who can.' (Heather)

Differences in the perceived experiences of teaching and learning were also evident at the point of course delivery (Table 4). Returning to the academic boredom survey instrument momentarily, 126 (70.4\%) respondents reported being engaged in tutorials most if not all of the time, with opportunities for interaction and support from staff and other students proving beneficial:

'Sometimes it's just to clarify what I didn't understand in the lecture ... [What] helps me is when they break it all down. I like to go with my questions and make sure those questions have been asked ... [T]he tutor doesn't know what I'm struggling with unless I bring it up.' (Lisa)

'We all kind of help each other in a way because everybody has different views ... There's always a debate or something being addressed ... a mix of everything.' (Hannah) 
Of the $53(29.6 \%)$ respondents engaged in tutorials less frequently, 13 were located in C1 (21.7\% of that cluster) with 7 located in C5 (46.7\% of that cluster), an overall difference which was not significant.

\section{[Insert Table 4 as close to here as possible.]}

As indicated earlier, traditional lectures fared less well, with only 74 (41.3\%) respondents engaged most if not all of the time. Those lectures with a perceived excess and inappropriate use of PowerPoint, together with a range of other factors, attracted particular criticism. This contributed strongly to the actual onset of academic boredom itself:

'Sometimes when lecturers have used a lot of PowerPoints and not really interacted with everyone in the lecture theatre it becomes a bit monotonous and my brain switches off. I don't like it when people turn the lights off ... that makes me more sleepy ... The speed of the content that's been covered in the lecture, especially if it's new ... I get completely muddled ... and the rest of the lecture becomes a blur ... you're catching up ... not concentrating, completely lost, and panicking a bit ... I feel frustrated at myself because I feel like I should be concentrating but then I also feel like "Why am I here?" ... It feels a bit pointless.' (Hannah)

In addition to interaction, pace, the relevance of content and actual conditions in the lecture theatre itself, many respondents also commented adversely on the personal attributes and qualities of the lecturer, including his or her own interest, enthusiasm and lecturing style as problematic (e.g. dictating from PowerPoints). Typical coping strategies included daydreaming, texting, doodling on handouts and talking to neighbours. Leaving at the earliest opportunity (e.g. a break in class) or resorting to Internet use and social media was rare as was being deliberately distracting. Of the $105(58.7 \%)$ respondents engaged less frequently in traditional lectures, 27 were located in $\mathrm{C} 1$ (45.0\% of that cluster) compared to 14 located in C5 $(93.3 \%$ of that cluster), a significant difference overall (ANOVA $F=3.611$, $d f=4,174 p<.01 ; \eta^{2}=.077$; greatest contrast between $\mathrm{C} 1$ and $\mathrm{C} 5 \mathrm{r}=.396)$.

Perceived course demands 
From the SETLQ, responses relating to course demands included many of the lowest scoring items observed (Table 3). In order of decreasing mean value across the questionnaire's two subscales (reflecting a transition from perceived easiness to difficulty), outcomes are presented as follows ( $S D=$ standard deviation):

- generic skills (mean $=3.66, \mathrm{SD}=0.631$ );

- prior knowledge and pace (mean=3.24, SD=658).

By way of example, while $143(79.9 \%)$ respondents found the use of information technology and computers relatively easy and straight forward (the highest scoring item overall), only $49(27.4 \%)$ thought the same of the amount of work they were expected to do (the lowest scoring item overall). Of the 130 (72.6\%) respondents who found this more demanding, 40 were located in $\mathrm{C} 1$ (66.7\% of that cluster) compared to 13 in C5 (86.7\% of that cluster). At interview, course demands were often related specifically to achievement motivation and progression year on year:

'In the first year I found it really straight forward. But when I realised the work I was doing actually meant something to my degree ... I want to get a better grade and I always aim to get a two-one [2:1] because I always think if people get, like, two-twos [2:2s] they look a bit like "Oh, you got a two-two [2:2], that's nearly a third, nearly a fail" but I always want to better myself.' (Lisa)

I think the first year was demanding ... just understanding what I had to do, the way things worked, that kind of thing. But as you move into the course it's more demanding ... the thought you have to put into it, how you have to analyse things. Things aren't black and white any more, things are shades of grey.' (Luke)

[I had to] resit my second year, l'd like to forget that happened. Definitely demanding. I wasn't ready for it at all. It's such a big step.' (Holly)

Scores were systematically lower in $\mathrm{C} 5$ than in $\mathrm{C} 1$ in all instances but only significantly so in 'generic skills' (ANOVA $F=7.034, d f=4,174 p<.001 ; \eta^{2}=.139$; greatest contrast between $\mathrm{C} 1$ and $\mathrm{C} 5 \mathrm{r}=.490$ ). In terms of individual items, the biggest range in scores observed was in tracking down information for themselves. More importantly, perhaps, and of the $70(39.1 \%)$ respondents who found this particularly demanding, 
only 18 were located in C1 (30.0\% of that group) compared to 10 in C5 (66.7\% of that group). Course demands were also found to impact on paid employment, time management and other pressures associated with being a student more generally:

'I had to give up a job before Christmas because I didn't feel there was enough time last semester, it felt quite hard to get everything done ... but I think it's hard to manage any kind of life, social life as well, 'cause you feel guilty if you're not working.' (Laura)

'[P]ersonal life makes it difficult ... struggling with two jobs, as well as bills and looking after a little 'un ... I tend to work better in the evenings so I might be up until three o' clock in the morning, get loads done, and just kip in the afternoon or something.' (Howie)

With some differences of opinion, including reference to the importance of being more organised, however, not all agreed.

\section{Path analysis}

The perceived experiences of teaching and learning subscale scores correlated weakly to moderately and negatively with BPS-UKHE scores as anticipated and with 'interest and enjoyment' in particular $(r=-.558, p<.001)$. Correlations with ways of working were also in the directions anticipated but distinctly more variable. Similar findings were also observed in course demands but with only 'generic skills' reaching any level of significance consistently. A full table of outcomes is presented as shown (Table 5). With only two minor but potentially important exceptions, 'set work and feedback' and 'interest and enjoyment' (weak and positive, $\mathrm{p}<.05$ ), significant correlations with final year degree outcome were notably absent and relevant to the path analysis which follows.

\section{[Insert Table 5 as close to here as possible]}

Path analysis, as an extension of multiple regression, is a statistical method used to provide simultaneous magnitude and significance estimates between a number of observed variables and the inferred directional relationships between them. It serves here as an exploratory modelling technique in-keeping with the work as a whole. While 
more robust, structural equation modelling was considered untenable on the basis of sample size alone. Located within C-VT, and guided by the working hypothesis presented in the introduction, a small number of indicative models were constructed and tested, all of which revealed academic trait boredom as a negative predictor of self-study, course demand (generic skills) and the respondents' perceived experiences of teaching and learning (presented here as the sum total of its component parts). These variables, in turn, positively predicted deep ways of working and organised effort. Course expectations, intrinsic value in particular, also contributed but in different ways (e.g. intrinsic value positively predicting deep ways of working). In terms of the final model presented (model fit indices ${ }^{2}: \boldsymbol{N}^{2}=33.83, \mathrm{df}=25$, $\mathrm{p}=.112 ; \mathrm{N}^{2} / \mathrm{df}=1.353 ; \mathrm{TLI}=0.951 ; \mathrm{CFI}=0.982 ; \mathrm{RMSEA}=0.022$ ), simplified to show only significant relationships (Figure 3 ), academic trait boredom's strongest contribution appears as a direct and negative predictor of organised effort (path coefficient $=-.40$ ) and a direct and positive predictor of surface ways of working (path coefficient $=.49$ ), accounting for $37 \%$ of the observed variance in surface scores alone. With all three ways of working appearing as mediators, the model as a whole accounted for $19 \%$ of the observed variance in final year degree outcome but with only organised effort and surface approaches doing so significantly. While alternative and more complex models cannot be entirely ruled out (e.g. with academic boredom operating as a moderating variable), its impact as an achievement-related emotion seems clear and deserving of greater attention than it currently receives.

\section{[Insert Figure 3 as close to here as possible]}

\section{Discussion}

Academic boredom: a neglected emotion

In this mixed-methods study of 179 final year Education Studies students attending a single university in England, the descriptive, inferential, cluster and path analysis of quantitative data provided unique insight into the relationships between academic trait boredom (an individual's propensity or habitual disposition towards getting bored at university), perceived course experiences and final year degree outcome. The content 
analysis of transcripts from research interviews complemented quantitative findings, indicating that those more prone to academic boredom than others had a sometimes similar but also qualitatively different set of course experiences, including that of academic boredom as a state (the actual experience of boredom by any individual at any given moment in time). This was most apparent in traditional lectures with a perceived excess and inappropriate use of PowerPoint together and other contributing factors (e.g. 93.3\% admitting to a lack of interest and engagement at least half of the time or more in C5 compared with $58.7 \%$ in C1), as well as during the completion of assignments for the purposes of assessment (see also Mann and Robinson, 2009; Authors, 2017a). Though not 'the lecture' or the use of PowerPoint per se, and bearable for the most part as the 'indifferent', 'calibrating' and 'searching' boredom described by Goetz et al. (2014), a variety of coping strategies were used to alleviate its effects.

With respect to academic boredom alone, overall findings both replicate and extend those reported in other studies conducted around the world, particularly with respect to adaptive learning behaviours, the redirection of cognitive resources, self-regulation and meta-cognitive awareness (e.g. Pekrun et al., 2009, 2010; Acee et al., 2010; Tze et al., 2013, 2016). Moreover, those students more prone to academic boredom than others were also more likely to be less intrinsically motivated, with some loss of purpose over time, more likely to describe their attendance at university as 'good' rather than 'excellent' and devote less time and effort to studying. Interestingly, and according to Curtis and Shani (2002), Kelly (2011), Gębka, (2013) and Oldfield et al. (2017), poor attenders in particular often have a lower sense of 'belongingness' at university, work more hours in paid employment, have more social life and family commitments and regularly struggle with coursework deadlines. Some of this was certainly evident here. Similarly, but with no sense of how effectively they were used, lower hours devoted to self-study can also be problematic (Kember et al., 1996; Rau and Durand, 2000; Plant et al., 2005). In combination with academic boredom, attributes such as these can eventually lead to dropping out and lower levels of retention (Respondek et al., 2017).

In terms of perceived course experiences, and while accommodating many of the cultural, contextual, disciplinary and other situational differences involved, findings are 
also in alignment with those of the ETLP (Entwistle 2008, 2009) and from Finland in particular, where cluster and path analysis have also been utilised to good effect (e.g. Parpala et al., 2010; Haarala-Muhonen et al., 2011; Rytkönen et al., 2012). The same is also broadly true of those studies conducted in Australia (e.g. Lizzio et al., 2002) and Norway (e.g. Diseth, 2002, 2007, 2013) despite differences in instrumentation. For those students more prone to academic boredom than others, however, the links between teaching and learning, the logical order of topics being studied, levels of support for progression and the practicalities of subject application were notably less clear, with the purpose and value of feedback often misunderstood. More 'state' than 'goal-oriented' (Eastwood et al., 2012), and responding to academic boredom more adversely as might be expected, surface approaches were more frequently adopted over others, with individuals accepting of things at face value and going through the motions of studying and learning rather than actively seeking the rewards associated with other ways of working (Trigwell et al., 2012; Authors, 2017b, submitted). Where findings differ mostly from other studies is in the close association between perceptions of heavy workload and surface approaches to learning. Here, workload did attract the lowest scores overall but this was felt 'equally' among all respondents, the final year participants perhaps more accustomed to this requirement. Paradoxically, but not uncommonly (Baeten et al., 2010), while largely successful in promoting and encouraging deeper ways of working with the intention of constructing meaning and understanding, this played little part in the actual prediction of degree outcome itself. Finally, and while modelled and tested from theory, the directional relationships presented in the path analysis do not imply causality. These are at least reciprocal and mutually reinforcing rather than linear, evidence for which already exists (Ramsden, 2003; Pekrun et al., 2014).

\section{Implications}

Implications arising from findings focus on boredom mitigation and supporting students even in their final year. This also extends to course design, course delivery and professional development for staff. Students themselves are, unfortunately, not always best placed to recognise their own emotions or to know about the impact that academic boredom can have on their work, regardless of age or background (Christie et al., 2008; Vogel-Walcutt et al., 2012; Kahu et al., 2015; Asikainen et al., 2017; 
Hagenauer et al., 2017). Between them, however, information derived from the academic boredom survey instrument, BPS-UKHE questionnaire and SETLQ, together with interviews, offer considerable diagnostic potential, not only for identifying those students most 'at risk' of falling behind and under-achieving but dropping out completely (Tait and Entwistle, 1996). They also give clues as to which intervention strategies might be most effective, including how students could helped towards becoming better learners, more meta-cognitively aware and taking increasing academic responsibility for themselves (Case and Gunstone, 2002; Pekrun et al., 2002; Entwistle and Peterson, 2004). Learning developers in particular are ideally positioned to help promote an awareness of academic boredom and how to deal with it, attribution retraining, goal setting and focusing on the benefits of positive emotions rather than negative (Ruthig et al., 2004; Haynes et al., 2009; Villavicencio and Bernardo, 2013). Those for whom academic boredom proves particularly troublesome, causing considerable anxiety or associated with depression in extreme cases, may also need to be referred to counsellors for the professional help that lecturers are not always qualified to provide (Ruthig et al., 2004; Goetz et al., 2010). Here, personal lives, work and family commitments and other demands beyond university which are known to help or impede progression can be better explored in confidence (Román et al., 2008; Haarala-Muhonen et al., 2011). Regular meetings with advisory or pastoral tutors and working collaboratively with other students may also lead to a greater sense of belonging (Garn et al., 2017).

Similarly, lecturers are not always aware of the importance of student emotions and how academic boredom impacts on engagement creating opportunities for professional development (Trowler, 2010; Gębka, 2013). In terms of how courses are designed and delivered, greater consideration could be directed towards how all of the many and varied elements involved in teaching are aligned constructively in order to provide the most stimulating learning environments possible (Kember and Leung, 2006; Biggs and Tang, 2011). This alone may require individual lecturers and course teams to become more critical and self-critical of their own professional practices as well as giving students a 'voice' in the various processes associated with course design and delivery themselves (Ashwin, 2015; Hailikari et al., 2016). Why different forms of academic practice are favoured over others, for example, could be more carefully articulated and reinforced regularly to help with academic integration and 
socialisation (Hughes and Smail, 2014). Lecturers also need to remain mindful of the importance of when and how best to introduce, sequence, pace and explain new materials particularly in the lecture theatre, while at the same time considering more innovative and creative uses of PowerPoint as a tool for disseminating information. They might also remain mindful of the motives, intentions and adaptations of students towards assessment requirements and how the choices they make can influence different ways of working, not all of which are necessarily productive or match intended learning outcomes (Gijbels et al., 2005). Students might certainly benefit, for example, from being given more options to choose from and greater autonomy to manage their own learning but with differential support as required. Assessment overlap and overload should certainly be avoided where possible, thereby providing opportunity for improved and more formative 'feedback' to 'feed forward' (Entwistle and Smith, 2002). Better organisation around coursework deadlines in order to spread workload demands would certainly be advantageous, while recognising that providing too much completion time (with the intention of being helpful) can often result in assignment boredom itself. Research conducted as part of the ETLP has demonstrated that ongoing assessment and the quality of feedback are major factors in determining student behaviour, achievement motivation, ways of working and course satisfaction (Entwistle, 2008, 2009). Though necessary if the student experience is to be improved, placing students more centre stage as outlined here may challenge the cultural traditions and pedagogical norms within some disciplines and departments more than others.

\section{Limitations}

Despite recent attention and advances in the field, the research presented here remains largely exploratory and inductive rather than explanatory and deductive, working within only a small part of the heuristic model and conceptual framework presented (Figure 1). As such, no work such as this can ever claim to adequately capture the heterogeneity of higher education provision, the nature and diversity of the student population, or the complexities associated with human behaviour such as it is. The collection and subsequent handling, modelling and interpretation of quantitative data using self-reporting instruments like questionnaires also relies upon a number of assumptions each of which introduces uncertainty. Among those often overlooked 
include a common understanding and interpretation of questionnaire items among respondents, using and transforming ordinal data for descriptive as well as other purposes, the treatment of questionnaire scales and subscales as observed rather than latent variables, and the temporal relationships considered to exist between variables in cluster and path analysis when measured simultaneously. Questionnaire fatigue, resulting in those students more prone to academic boredom than others absenting themselves from participating during repeated phases of data collection (or simply being absent in class), certainly resulted in some sample mortality with a corresponding reduction in sample size overall (and in C5 in particular). Similarly, judgements arising from qualitative data relied upon the retrospective attribution of meaning without opportunity for independent verification over time. Both questionnaires and interviews can also suffer from other unwanted effects including social desirability bias, image management, integrity and honesty and the general emotional state of respondents at the time of participation. Further experimental and longitudinal research, employing different instruments and analytical techniques, considering course experiences more developmentally, or by isolating and studying individual cluster populations, is required if findings are to be replicated and extended or otherwise, particularly as relationships may be influenced by sometimes very specific and highly localised if extraneous effects (e.g. the age, sex and background of individual lecturers, appearance and personality over substance, group dynamics, grade expectation, and so on).

\section{Conclusion}

Making a valuable contribution to the still underdeveloped field of achievement-related emotions in the UK, this work demonstrates the value of mixed-methods designs which integrate questionnaires with research interviews to provide exploratory but effective probes of academic boredom and perceived course experiences which together impact upon overall academic performance and achievement. As a negative and disabling achievement-related emotion, the effects of academic boredom reported here were far reaching with implications that cannot surely be ignored. Looking beyond the boundaries of our own work, however, we are reminded by Entwistle that: 
"[I]n the end, "best practice" is whatever helps students to engage more deeply with the subject and to become more actively responsible for their own learning, in the context of the goals of a particular institution, degree course, and particular group of students at a particular stage of their degree. And deciding what that involves is no small challenge to faculty.' (2008:32)

As implied by Entwistle, however, to consider that academic performance and achievement can be improved by simply changing practice alone would be overly simplistic in the extreme. Students also need to be more actively involved in their own courses, identifying and responding to the effects of academic boredom and contributing as best they can. With academic boredom an integral part of a greater emotional dynamic and evolving network of other factors now known to influence how learning takes place, however, new and exciting lines of enquiry have yet to come.

\section{Acknowledgements}

The authors would like to thank colleagues Barbara Murphy, Sam Elliott and Ellie Foster for their assistance with conducting and transcribing the research interviews.

\section{Notes}

1. SPSS (Statistical Package for the Social Sciences) is an IBM software package commonly used in educational research to interrogate the quantitative datasets obtained from questionnaires. Principal Component Analysis (PCA) was used here to explore whether or not the different components or scales and subscales of the Shortened Experiences of Teaching and Learning Questionnaire or SETLQ, its principal components, were sufficiently robust to use beyond the context in which they were originally presented. Oblique rotation is favoured when high correlations between components are anticipated or known to exist. The Keiser-Meyer-Olkin (KMO) value provides a measure of sampling adequacy with values over 0.8 considered acceptable. Bartlett's test of sphericity $\left(\mathrm{K}^{2}\right)$ provides a measure of whether or not any components can be identified at all. A significant outcome is desirable $(p<.05)$, Eigenvalues help determine the number and relative importance of individual components themselves. Components with eigenvalues less than 1.0 are often 'discarded'.

2. AMOS (Analysis of Moment Structures) is a modular package available within SPSS which allows path diagrams to be constructed and interrogated by graphical means. The extent to which a path diagram adequately models variable relationships is usually reported using a range of fit indices, the values of which vary slightly from source to source. Non-significant chi-square $\left(\aleph^{2}\right)$ values are desirable ( $p>$.05) but complex models often violate this criterion. The relative or normed indicator $\left({ }^{2} / \mathrm{df}\right)$ provides a useful alternative. Values less than 3 are acceptable. For the Tucker-Lewis Index (TLI) and Comparative Fit Index (CFI), values greater than 0.90 are acceptable. One of the most reliable measures of 'goodness of fit' is the Root Mean Square Error of Approximation (RMSEA). Values less than 0.08 are acceptable but 0.05 preferred. 


\section{References}

Authors (2016) Towards a model for the assessment of student boredom and boredom proneness in the UK higher education context.

Authors (2017a) Academic boredom among students in higher education: a mixed-methods exploration of characteristics, contributors and consequences.

Authors (2017b) Academic boredom, the approaches to learning and the final-year degree outcomes of undergraduate students.

Authors (submitted) The relationship between academic trait boredom, learning approach and university achievement.

Acee, T.W., Kim, H., Kim, H.J., Chu, H.R., Kim, M., Cho, Y. and Wicker, F.W. (2010) Academic boredom in under- and over-challenging situations. Contemporary Educational Psychology, 35(1), 17-27.

Ashwin, P. (ed.) (2015) Reflective teaching in Higher Education. London: Bloomsbury.

Asikainen, H., Hailikari, T. and Mattson, M. (2017) The interplay between academic emotions, psychological flexibility and self-regulation as predictors of academic achievement. Journal of Further and Higher Education. [Available online].

Baeten, M., Kyndt, E., Struyvan, K. and Dochy, F. (2010) Using student-centred learning environments to stimulate deep approaches to learning: factors encouraging or discouraging their effectiveness. Educational Research Review, 5(3), 243-260.

Bench, S.W. and Lench, H.C. (2013) On the function of boredom. Behavioral Sciences, 3, 459-472.

Biggs, J. and Tang, C. (2011) Teaching for quality learning at university. Maidenhead: Society for Research into Higher Education and Open University Press.

British Educational Research Association (2011) Ethical guidelines for educational research. London: BERA. [Available at: www.bera.ac.uk/researchersresources/publications/ethical-guidelines-for-educational-research-2011.]

Byrne, B.M. (2013) Structural equation modelling with AMOS: basic concepts, applications and programming. New York: Routledge. 
Case, J.M. and Gunstone, R.F. (2002) Metacognitive development as a shift in approach to learning: an in-depth study. Studies in Higher Education, 27(4), 459- 470.

Christie, H., Tett, L., Cree, V.E., Hounsell, J. and McCune, V. (2008) 'A real rollercoaster of confidence and emotions': learning to be a university student. Studies in Higher Education, 33(5), 567-581.

Cohen, L., Manion, L. and Morrison, K. (2011) Research methods in education. London: Routledge.

Creswell, J.W. and Plano-Clark, V.L.P. (2011) Designing and conducting mixed methods research. Thousand Oaks, CA: Sage.

Curtis, S. and Shani, N. (2002) The effect of taking paid employment during termtime on students' academic studies. Journal of Further and Higher Education, 26(2), 129-138.

Diseth, A. (2002) The relationship between intelligence, approaches to learning and academic achievement. Scandinavian Journal of Educational Research, 46(2), 219-230.

Diseth, Å. (2007) Approaches to learning, course experience and examination grade among undergraduate psychology students: testing of mediator effects and construct validity. Studies in Higher Education, 32(3), 373-388.

Diseth, A. (2013) Personality as an indirect predictor of academic achievement via student course experience and approaches to learning. Social Behaviour and Personality, 41(8), 1297-1308.

Eastwood, J.D., Frischen, A., Fenske, M. and Smilek, D. (2012) The unengaged mind: defining boredom in terms of attention. Perspectives on Psychological Science, 7(5), 482-495.

Elpidorou, A. (2017) The good of boredom. Philosophical Psychology. [Available online.]

Entwistle, N.J. (2008) Taking stock: teaching and learning research in higher education. Paper presented at the Ontario International Symposium on teaching and learning in Higher Education, May 2008. 45pp.

Entwistle, N.J. (2009) Teaching for understanding at university. London: Palgrave Macmillan. 
Entwistle, N.J. and Peterson, E. (2004) Conceptions of learning and knowledge in higher education: relationships with study behaviour and influences of learning environments. International Journal of Educational Research, 41(6), 407-428.

Entwistle, N.J. and Ramsden, P. (1983) Understanding student learning. London: Croon Helm.

Entwistle, N. and Smith, C.A. (2002) Personal understanding and target understanding: mapping influences on the outcomes of learning. British Journal of Educational Psychology, 72(3), 321-342.

Entwistle, N., McCune, V. and Hounsell, J. (2002) Approaches to studying and perceptions of university teaching-learning environments: concepts, measures and preliminary findings. Occasional Report 1. Available at: www.etl.tla.ed.ac.uk/docs/ETLreport1.pdf.

Fahlman, S.A., Mercer-Lynn, K.B., Flora, D.B. and Eastwood, J.D. (2013) Development and validation of the multidimensional state boredom scale. Assessment, 20(1), 68-85.

Farmer, R. and Sundberg, N.D. (1986) Boredom proneness: the development and correlates of a new scale. Journal of Personality Assessment, 50(1), 4-17.

Field, A. (2013) Discovering statistics using IBM SPSS. London: Sage.

Fisher, C.D. (1993) Boredom at work: a neglected concept. Human Relations, 46(3), 395-418.

Fontana, A. and Frey, J.H. (2000) The interview: from structured questions to negotiated text. In: N.K. Denzin and Y.S. Lincoln (eds.) Handbook of qualitative research. Thousand Oaks, CA: Sage. 645-672.

Garn, A.C., Simonton, K., Dasingert, T. and Simonton, A. (2017) Predicting changes in student engagement in university physical education: application of the control-value theory of achievement emotions. Psychology of Sport and Exercise, 29, 93-102.

Gębka, B. (2017) Psychological determinants of university students' academic performance: an empirical study. Journal of Further and Higher Education, 38(6), 813-837.

Gijbels, D., Van de Watering, G., Dochy, F. and Van den Bossche, P. (2005) The 
relationship between student' approaches to learning and the assessment of learning outcomes. European Journal of Psychology of Education, 20(4), 327341.

Goetz, T., Frenzel, A.C., Hall, N.C., Nett, U.E., Pekrun, R. and Anatstasiya, A.L. (2014) Types of boredom: an experience sampling approach. Motivation and Emotion, 38(3), 401-419.

Goetz, T., Frenzel, A.C., Stoeger, H. and Hall, N.C. (2010) Antecedents of everyday positive emotions: an experience sampling analysis. Motivation and Emotion, 34(1), 49-62.

Goldberg, Y.K., Eastwood, J.D., Laguardia, J. and Danckert, J. (2011) Boredom: an emotional experience distinct from apathy, anhedonia, or depression. Journal of Social and Clinical Psychology, 30(6), 647-666.

Gorard, S. (2004) Sceptical or clerical? Theory as a barrier to the combination of research methods. Journal of Educational Enquiry, 5(1), 1-21.

Greene, J.C. (2007) Mixed methods in social inquiry. San Francisco, CA: JosseyBass.

Greenson, R. (1953) On Boredom. Journal of the American Psychoanalytical Association, 1(1), 7-21.

Haarala-Muhonen, A., Ruohoniemi, M., Katajavuori, N. and Lindblom-Ylänne, S. (2011) Comparison of students' perceptions of their teaching-learning environments in three professional academic disciplines: a valuable tool for quality enhancement. Learning Environments Research, 14, 155-169.

Hagenauer, G., Gläser-Zikuda, M. and Moschner, B. (2017) University students' emotions, life-satisfaction and study commitment: a self-determination theoretical perspective. Journal of Further and Higher Education. [Available online.]

Hailikari, T., Tuononen, T. and Parpala, A. (2016) Students' experiences of the factors affecting their study progress: differences in study profiles. Journal of Further and Higher Education. Available online. 1-12.

Haladyn, J.J. (2015) Boredom and art: passions of the will to boredom. Alresford: Zero Books.

Harris, M.B. (2000) Correlates and characteristics of boredom proneness and boredom. Journal of Applied Social Psychology, 30(3), 576-598. 
Haynes, T.L., Perry, R.P., Stupnisky, R.H. and Daniels, L.M. (2009) A review of attributional retraining treatments: fostering engagement and persistence in vulnerable college students. In: J.C. Smart (ed.) Higher Education Handbook of Theory and Research. Dordrecht: Springer. 227-272.

Healy, S.D. (1986) Boredom, self and culture. New Jersey: Fairleigh Dickenson.

Heron, W. (1957) The pathology of boredom. Scientific American, 196, 52-56.

Ho, R. (2014) Handbook of univariate and multivariate data analysis with IBM statistics. Boca Raton: Taylor and Francis.

Hounsell, D. and Entwistle, N. (2005) Enhancing teaching-learning environments in undergraduate courses: final report to the Economic and Social research Council. Edinburgh: University of Edinburgh. Available at: www.etl.tla.ed.ac.uk.

Hughes, G. and Smail, O. (2014) Which aspects of university life are most and least helpful in the transition to HE? A qualitative snapshot of student perceptions. Journal of Further and Higher Education, 39(4), 466-480.

Illeris, K. (2003) The three dimensions of learning: contemporary learning theory in the tension field between the cognitive, the emotional and the social. Leicester: NIACE.

Johnson, R.B., Onwuegbuzie, A.J. and Turner, L.A. (2007) Toward a definition of mixed methods research. Journal of Mixed Methods Research, 1(2), 112-133.

Kahu, E., Stephens, C, Leach, L. and Zepke, N. (2015) Linking academic emotions and student engagement: mature-aged distant students' transition to university. Journal of Further and Higher Education, 39(4), 481-497.

Kelly, G.C. (2011) Lecture attendance rates at university and related factors. Journal of Further and Higher Education, 36(1), 17-40.

Kember, D. (2004) Interpreting student workload and the factors which shape students' perceptions of their workload. Studies in Higher Education, 29(2), 165-184.

Kember, D. and Leung, D. (2006) Characterising a teaching and learning environment conducive to making demands on students while not making their workload excessive. Studies in Higher Education, 31(2), 185-198.

Kember, D., Harrison, T.S.E., Wong, E.T.T. and Pomfrett, M. (1996) An examination 
of the inter-relationships between workload, study time, learning approaches and academic outcomes. Studies in Higher Education, 21(3), 347-358.

Lewinsky, H. (1943) Boredom. British Journal of Educational Psychology, 13(3), 147-152.

Lindblom-Ylänne, S., Trigwell, K., Nevgi, A. and Ashwin, P. (2006) How approaches to teaching are affected by discipline and teaching context. Studies in Higher Education, 31(3), 285-298.

Linnenbrink-Garcia, E.A. and Pekrun, R. (2011) Students' emotions and academic engagement. Contemporary Educational Psychology (Special Issue), 36(1), 13.

Lizzio, A., Wilson, K. and Simons, R. (2002) University students' perceptions of the learning environment and academic outcomes: implications for theory and practice. Studies in Higher Education, 27(1), 27-52.

Loon, M. and Bell, R. (2017) The moderating effects of emotions on cognitive skills. Journal of Further and Higher Education. [Available online.]

Malkovsky, E., Merrifield, C., Goldberg, Y. and Danckert, J. (2012) Exploring the relationship between boredom and sustained attention. Experimental Brain Research, 221, 59-67.

Mann, S. (2016) The upside of downtime: why boredom is good. London: Robinson.

Mann, S. and Robinson, A. (2009) Boredom in the lecture theatre: an investigation into the contributors, moderators and outcomes of boredom amongst university students. British Educational Research Journal, 35(2), 243-258.

Mason, J. (2002) Qualitative researching. London: Sage.

Mercer-Lynn, K.B., Flora, D.B., Fahlman, S.A. and Eastwood, J.D. (2011) The measurement of boredom: differences between existing self-report scales. Assessment, 20(5), 585-596.

Mikulas, W.L. and Vodanovich, S.J. (1993) The essence of boredom. The Psychological Record, 43(1), 3-12.

Miles, M.B., Huberman, A.M. and Saldaña, J. (2014) Qualitative data analysis: a methods sourcebook. London: Sage.

Moynihan, A.B., Van Tilberg, W.A.P., Igou, E.R., Wiseman, A., Donnelley, A.E. and 
Mulcaire, J.B. (2015) Eaten up by boredom: consuming food to escape awareness of the bored self. Frontiers in Psychology, 6, 369.

Moroldo, G.K. (1986) Shyness, boredom and grade point average among college students. Psychological Reports, 59(2), 395-398.

Nijhuis, J., Segers, M. and Gijselaers, W. (2008) The extent of variability in learning strategies and student perceptions of the learning environment. Learning and Instruction, 18, 121-134.

O'Connor, D. (1967) The phenomenon of boredom. Journal of Existentialism, 7(27), 381-399.

O'Hanlon, J.F. (1981) Boredom: practical consequences and a theory. Acta Psychologica, 49(1), 53-82.

Oldfield, J., Rodwell, J., Curry, L. and Marks, G. (2017) Psychological and demographic predictors of undergraduate non-attendance at university lectures and seminars. Journal of Further and Higher Education. Available online. 1-15.

Parpala, A., Lindblom-Ylänne, S., Komulainen, E., Litmanen, T. and Hirsto, L. (2010) Students' approaches to learning and their experiences of the teaching-learning environment in different disciplines. British Journal of Educational Psychology, 80(2), 269-282.

Parpala, A., Lindblom-Ylänne, S., Komulainen, E. and Entwistle, N. (2013)

Assessing students' experiences of teaching-learning environments and approaches to learning: validation of a questionnaire used in different countries and varying contexts. Learning Environment Research, 16(2), 201-215.

Pekrun, R. (2000) A social-cognitive, control-value theory of achievement emotions. In: J. Heckhausen (ed.) Motivational psychology of human development. Oxford: Elsevier Science. 143-163.

Pekrun, R. (2006) The control-value theory of academic emotions: assumptions, corollaries and implications for educational practice. Educational Psychology Review, 18(4), 315-341.

Pekrun, R. and Stevens, E.J. (2010) Achievement emotions: a control-value approach. Social and Personality Psychology Compass, 4, 238-255.

Pekrun, R., Elliot, A.J. and Maier, M.A. (2009) Achievement goals and achievement emotions: testing a model of their joint relations with academic performance. Journal of Educational Psychology, 101(1), 115-135. 
Pekrun, R., Goetz, T., Daniels, L.M., Stupinsky, R.H. and Perry, R.P. (2010) Boredom in achievement setting: exploring control-value antecedents and performance outcomes of a neglected emotion. Journal of Educational Psychology, 102(3), 531-549.

Pekrun, R., Goetz, T. Frenzel, A.C., Barchfeld, P., and Perry, R.P. (2011) Measuring emotions in students' learning and performance: the Achievement Emotions Questionnaire. Contemporary Educational Psychology, 36(1), 36-48.

Pekrun, R., Goetz, T., Titz, W.and Perry, R.P. (2002) Academic emotions in students' self-regulated learning and achievement: a programme of quantitative and qualitative research. Educational Psychologist, 37(2), 91-106.

Pekrun, R., Hall, N.C., Goetz, T. and Perry, R.P. (2014) Boredom and academic achievement: testing a model of reciprocal causation. Journal of Educational Psychology, 106(3), 696-710.

Perkins, R.E. and Hill, A.B. (1985) Cognitive and affective aspects of boredom. British Journal of Psychology, 76, 221-234.

Powney, J. and Watts, M. (1987) Interviewing in educational research. London: Routledge.

Plant, E.A., Ericsson, K.A., Hill, L. and Asberg, K. (2005) Why study time does not predict grade point average across college students: implications for deliberate practice for academic performance. Contemporary Educational Psychology, 30, 96-116.

Prosser, M. and Trigwell, K. (1999) Understanding learning and teaching: the experience in Higher Education. Buckingham: SRHE.

Ramsden, P. (1991) A performance indicator of teaching quality in higher education. Studies in Higher Education, 16(2), 129-150.

Ramsden, P. (2003) Learning to teach in higher education. London: RoutledgeFalmer.

Rau, W. and Durand, A. (2000) The academic ethic and college grades: does hard work help students to 'make the grade'? Sociology of Education, 73(1), 19-38.

Respondek, L., Seufert, T., Stupnisky, R. and Nett, U.E. (2017) Perceived academic control and academic emotions predict undergraduate university student success: examining effects in dropout intention and achievement. Frontiers in Psychology, 8(243), 1-18. 
Richardson, J.T.E. (2004) Methodological issues in questionnaire-based research on student learning in higher education. Educational Psychology Review, 16(4), 347-358.

Richardson, J.T.E. (2005) Instruments for obtaining student feedback: a review of the literature Assessment and Evaluation in Higher Education, 30(4), 387-415.

Richardson, J.T.E. (2014). Critical synthesis package: experiences of teaching and learning questionnaire (ETLQ). Washington: Association of American Medical Colleges.

Román, S., Cuestas, P. and Fenollar, P. (2008) An examination of the interrelationships between self-esteem, others' expectations, family support, learning approaches and academic achievement. Studies in Higher Education, 33(2), 127-138.

Ruohoniemi, M. and Lindblom-Ylänne, S. (2009) Students' experiences concerning course workload and factors enhancing and impeding their learning - a useful resource for quality enhancement in teaching and curriculum planning. International Journal of Academic Development, 14(1), 69-81.

Russell, J.A. (1980) A circumplex model of affect. Journal of Personality and Social Psychology, 39(6), 1161-1178.

Ruthig, J.C., Perry, R.P., Hall, N.C. and Hladkyj, S. (2004) Optimism and attributional retraining: longitudinal effects on academic achievement, test anxiety and voluntary course withdrawal in college students. Journal of Applied Social Psychology, 34(4), 709-730.

Ruthig, J.C., Perry, R.P., Hladkyj, S., Hall, N.C., Pekrun, R. and Chipperfield, J.G. (2008) Perceived control and emotions: interactive effects on performance in achievement settings. Social Psychology of Education, 11(2), 161-180.

Rytkönen, H., Parpala, A., Lindblom-Ylänne, S., Virtanen, V. and Postareff, L. (2012) Factors affecting bioscience students' academic achievement. Instructional Science, 40(2), 241-256.

Saldaña, J. (2013) The coding manual for qualitative research. London: Sage.

Schostack, J.F. (2006) Interviewing and representation in qualitative research projects. Buckingham: Open University Press. 
Schutz, P.A. and Pekrun, R. (eds.)(2007) Emotion in education. Burlington, MA: Academic Press.

Skues, J., Williams, B., Oldmeadow, J. and Wise, L. (2016) The effects of boredom, loneliness, and distress tolerance on problem internet use among university students. International Journal of Mental Health and Addiction, 14(2), 167-180.

Smith, R.P. (1981) Boredom: a review. Human Factors, 23(3), 329-340.

Spacks, P.M. (1995) Boredom: the literary history of a state of mind. Chicago: University of Chicago Press.

Svendsen, L. (2005) A philosophy of boredom. London: Reaktion Books.

Swanberg, A.B. and Martinsen, Ø.L. (2010) Personality, approaches to learning and achievement. Educational Psychology, 30(1), 75-88.

Tait, H. and Entwistle, N. (1996) Identifying students at risk through ineffective study strategies. Higher Education, 31(1), 97-116.

Tashakkori, A. and Teddlie, C. (1998) Mixed methodology: combining qualitative and quantitative approaches. Thousand Oaks, CA: Sage.

Todman, M. (2003) Boredom and psychotic disorders: cognitive and motivational issues. Psychiatry, 66 (2), 146-167.

Toohey, P. (2012) Boredom: a lively history. New Haven: Yale University Press.

Trigwell, K., Ellis, R.A. and Han, F. (2012) Relations between students' approaches to learning, experienced emotions and outcomes of learning. Studies in Higher Education, 37(7), 811-824.

Trowler, V. (2010) Student engagement: evidence summary. York: Higher Education Academy.

Tze, V.M.C., Klassen, R.M., Daniels, L.M. and Li, J.C-H. (2013) Canadian and Chinese university students' approaches to coping with academic boredom. Learning and Individual Differences, 23, 32-43.

Tze, V.M.C., Klassen, R.M. and Daniels, L.M. (2014) Patterns of boredom and its relationship with perceived autonomy support and engagement. Contemporary Educational Psychology, 39(3), 175-187.

Tze, V., Daniels, L.M. and Klassen, R.M. (2016) Evaluating the relationship between 
boredom and academic outcomes: a meta-analysis. Educational Psychology Review, 28(1), 119-144.

Van Tilberg, W.A.P. and Igou, E.R. (2012) On boredom: lack of challenge and meaning as distinct boredom experiences. Motivation and Emotion, 36(2), 181194.

Villavicencio, F.T. and Bernardo, A.B.I. (2013) Positive academic emotions moderate the relationship between self-regulation and academic achievement. British Journal of Educational Psychology, 83(2), 329-340.

Vodanovich, S.J. (2003a) On the possible benefits of boredom: a neglected area of personality research. Psychology and Education: An Interdisciplinary Journal, 40(3/4), 28-33.

Vodanovich, S.J. (2003b) Psychometric measures of boredom: a review of literature. The Journal of Psychology, 137(6), 569-595.

Vodanovich, S.J. and Watt, J.D. (2016) Self-report measures of boredom: an updated review of the literature. The Journal of Psychology, 150(2), 196-228.

Vogel-Walcutt, J.J., Fiorella, L., Carper, T. and Schatz, S. (2012) The definition, assessment and mitigation of state boredom within educational settings: a comprehensive review. Educational Psychology Review, 24(1), 89-111.

Zhang, L. (2003) Does the Big Five predict learning approaches? Personality and Individual Differences, 34, 1431-1445. 


\section{Appendix 1: The BPS-UKHE questionnaire (18-item 'short-form')}

\section{Academic trait boredom}

Scale: A - Always (Score 5), B - Usually (Score 4), C - Occasionally (Score 3), D - Rarely (Score 2), E - Never (Score 1)

Tedium (reliability $\alpha=0.845$; skewness=0.454; kurtosis=0.256)

At university, I find myself trapped in situations where I have to do meaningless things.

At university, having to read someone else's coursework or watch their presentation and listen to what they have to say bores me tremendously.

At university, many things I have to do are repetitive and monotonous.

At university, I get a kick out of most things I do.*

I find it difficult to get excited about my work at university.

At university, it is very hard for me to find a task that is exciting enough.

Unless I am doing something exciting at university I feel half dead and dull.

At university it seems that we do the same things all the time - it's getting old.

I've found everything about university monotonous and tiresome.

Concentration (reliability $\alpha=0.727$; skewness $=0.030$; kurtosis $=-0.207$ )

At university, I find it easy to concentrate on my work and other activities. ${ }^{*}$

I find it easy to entertain and motivate myself at university. ${ }^{*}$

At university, it takes more stimulation to get me going than most people.

Time (reliability $\alpha=0.635$; skewness=0.573; kurtosis $=-0.106$ )

Time seems to pass by slowly for me at university.

At university, I find myself at a 'loose end' not knowing what to do.

At university, I have no shortage of projects in mind and things to do.*

In any situation at university, I can find something to do or see to keep me interested.*

At university, I find myself just sitting around doing nothing.

At university, I often find myself with time on my hands and nothing to do.

Full scale statistics (reliability $\alpha=0.892 ;$ skewness $=0.324$; kurtosis $=0.191$ )

Source: Authors (2016) after the BPS of Farmer and Sundberg (1986)

Scale and subscale scoring procedure: transform reverse score items $\left({ }^{*}\right)$ before adding individual items together and dividing by the relevant number of items to obtain mean values. With both advantages and disadvantages, reverse-score items are included to encourage respondents to read each item carefully thereby minimising respondent bias. As higher scores indicate a greater propensity towards academic boredom, 'positively' worded items must be adjusted accordingly (e.g. a score of 5 is changed to 1 , a score of 4 is changed to 2 , and so on). 


\section{Appendix 2: Shortened Experiences of Teaching and Learning Questionnaire}

Scale: Strongly agree (Score 5), Agree (Score 4), Neutral (Score 3), Disagree (Score 2), Strongly disagree (Score 1)

\section{Course expectations}

Intrinsic value (reliability $\alpha=0.581$; skewness $=-0.418$; kurtosis=-0.091)

It was a course I thought would be interesting rather than easy.

I hoped the things I would learn would help me to develop as a person and broaden my horizons.

I wanted to learn things which might let me help people and/or make a difference in the world.

I wanted to study my subject in depth by taking interesting and stimulating modules.

Personal/social (reliability $\alpha=0.626$; skewness=-1.424; kurtosis=2.863)

Opportunities for an active social life and/or sport.

I hoped the whole experience here would make me more independent and self-confident.

Career (reliability $\alpha$ - ; skewness $=-1.126$; kurtosis $=0.700$ )

I mainly needed the qualification to enable me to get a good job when I finished.

Lack of purpose (reliability $\alpha$ - ; skewness $=1.306$; kurtosis=0.990)

When I look back, I sometimes wonder why I ever decided to come here.

\section{Ways of working (approaches to studying and learning)}

Deep (reliability $\alpha=0.775$; skewness $=0.878$; kurtosis $=2.684$ )

I usually go over the work l've done to check my reasoning to see that it makes sense.

In making sense of new ideas, I often relate them to practical or real life contexts.

Ideas I've come across in my academic reading often set me off on long chains of thought.

I look at evidence carefully to reach my own conclusions about what I'm studying.

When l've been communicating ideas, I've thought over how well l've got my points across.

It has been important to me to follow the argument or to see the logic behind things.

I try to find better ways of tracking down relevant information in this subject.

In reading for this course, I try to find out for myself exactly what each author means.

If I've not understood things well enough when studying I try a different approach.

Organised effort (reliability $\alpha=0.761$; skewness $=-0.595$; kurtosis $=-0.104$ )

I generally put a lot of effort into my studying.

On the whole, I'm quite systematic and organised in my studying.

I organise my study time carefully to make the best use of it.

Concentration has not usually been a problem for me unless I've been really tired.

Surface (reliability $\alpha=0.674$; skewness $=0.039$; kurtosis $=-0.443$ )

I often have trouble making sense of the things I have to remember.

A lot of what I learn seems no more than lots of unrelated bits and pieces in my mind.

I tend to take what we've been taught at face value without questioning it much.

l've just been going through the motions of studying without seeing where l'm going.

\section{Perceived experiences of teaching and learning}

Aims and congruence (reliability $\alpha=0.776$; skewness=-0.632; kurtosis $=1.302$ )

It was clear to me what I was supposed to learn during the course.

The topics seemed to follow each other in a way that made sense to me.

What we were taught seemed to match what we were supposed to learn.

The handouts and other materials we were given helped me to understand the course.

I could see how the set work fitted in with what we were supposed to learn.

Choice allowed (reliability $\alpha=0.704$; skewness=-0.709; kurtosis=0.428)

We were given a good deal of choice over how we went about learning.

We were allowed some choice over what aspects of the subject to concentrate on.

Teaching for understanding (reliability $\alpha=0.776$; skewness $=-0.589$; kurtosis $=0.397$ )

On this unit I was prompted to think about how well I was learning and how I might improve.

The teaching encouraged me to rethink my understanding of some aspects of the subject.

This course has given me a sense of what goes on 'behind the scenes' in this subject area. 
The teaching on this course helped me to think about the evidence underpinning different views.

This course encouraged me to relate what I learned to issues in the wider world.

Set work and feedback (reliability $\alpha=0.828$; skewness=-0.656; kurtosis=1.246)

It was clear to me what was expected in the assessed work for this course.

I was encouraged to think about how best to tackle the set work.

The feedback given on my work helped me to improve my ways of learning and studying.

Staff gave me the support I needed to help me complete the set work for this course.

The feedback given on my set work helped to clarify things I hadn't fully understood.

Critical thinking (reliability $\alpha=0.676$; skewness $=-0.432$; kurtosis $=0.111$ )

You had to really understand the subject to get good marks on this course.

To do well in this course you had to think critically about the topics studied.

Support from staff and students (reliability $\alpha=0.638$; skewness $=-0.408$; kurtosis $=0.092$ )

Staff tried to share their enthusiasm about the subject with us.

Staff were patient in explaining things which seemed difficult to grasp.

Students supported each other and tried to give help when it was needed.

Talking with other students has helped me to develop my understanding. Interest and enjoyment (reliability $\alpha=0.879$; skewness $=-0.812$; kurtosis=1.425)

I found most of what I learned on this course really interesting.

I've enjoyed being involved in this course.

\section{Perceived course demands}

Scale: Very easy (Score 5), Fairly easy (Score 4), Neutral (Score 3), Fairly difficult (Score 2), Very difficult (Score 1).

Prior knowledge and pace (reliability $\alpha=0.736$; skewness $=-0.239$; kurtosis=-0.439)

What I was expected to know to begin with.

The rate at which new material was introduced.

The ideas and problems I had to deal with.

The skills or technical procedures needed for this subject.

The amount of work I was expected to do.

Generic skills (reliability $\alpha=0.657$; skewness $=-0.359$; kurtosis $=-0.341$ )

Working with other students.

Organising and being responsible for my own learning

Communicating knowledge and ideas effectively.

Tracking down information for myself.

Using information technology and computing skills.

Source: Adapted from Entwistle et al. (2002)

Scoring procedure: for all subscales, add relevant item scores together before dividing by the number of items to obtain mean values. 


\begin{tabular}{lr}
\hline Characteristic & Frequency (\%) \\
\hline Sex & \\
Male & $41(22.9)$ \\
Female & $138(77.1)$ \\
Age starting university & \\
under 21 & $136(76.0)$ \\
$21-25$ & $29(16.2)$ \\
$26-30$ & $4(2.2)$ \\
$31-40$ & $5(2.8)$ \\
over 40 & $5(2.8)$ \\
Entry qualifications & \\
A-levels & $157(87.7)$ \\
A-level equivalents & $22(12.3)$ \\
University generation & $119(66.5)$ \\
First order & $60(33.5)$ \\
Higher order & \\
Occupational background & $74(41.3)$ \\
Professional & $102(57.0)$ \\
Manual & $3(1.7)$ \\
Other & \\
Working to earn money while studying & $106(59.2)$ \\
Yes & $73(40.8)$ \\
No & \\
Attendance & $120(67.0)$ \\
Excellent & $53(29.6)$ \\
Good & $5(2.8)$ \\
Satisfactory & $1(0.6)$ \\
Poor & \\
\hline
\end{tabular}

Table 1 Respondent profile $(n=179)$ 


\begin{tabular}{|c|c|c|c|c|c|c|c|c|c|c|}
\hline & \multirow[b]{2}{*}{ BPS-UKHE } & \multirow[b]{2}{*}{ Deep } & \multirow[b]{2}{*}{$\begin{array}{c}\text { Organised } \\
\text { effort }\end{array}$} & \multirow[b]{2}{*}{ Surface } & \multicolumn{4}{|c|}{ Course expectations } & \multirow[b]{2}{*}{$\begin{array}{c}\text { Self-study } \\
\text { (hours/week) }\end{array}$} & \multirow[b]{2}{*}{$\begin{array}{c}\text { Degree } \\
(\%)\end{array}$} \\
\hline & & & & & $\begin{array}{c}\text { Intrinsic } \\
\text { value }\end{array}$ & $\begin{array}{c}\text { Personal/ } \\
\text { social }\end{array}$ & Career & $\begin{array}{l}\text { Lack of } \\
\text { purpose }\end{array}$ & & \\
\hline BPS-UKHE & - & $-.421^{* \star *}$ & $-.527^{\star \star \star}$ & $.586^{\star \star \star}$ & $-.375^{\star \star \star}$ & $.089^{\text {ns }}$ & $-.016^{\mathrm{ns}}$ & $.489^{\star \star \star}$ & $-.288^{\star \star \star}$ & $-.318^{\star \star \star}$ \\
\hline Deep & & - & $.523^{\star \star \star}$ & $-.281^{* \star *}$ & $.533^{\star \star \star}$ & $.048^{\text {ns }}$ & $.152^{*}$ & $-.259^{* * *}$ & $.345^{\star \star \star}$ & $.171^{*}$ \\
\hline Organised effort & & & - & $-.279^{\star \star *}$ & $.308^{\star \star \star}$ & $-.013^{\text {ns }}$ & $.155^{\star}$ & $-.317^{* * *}$ & $.342^{\star \star \star}$ & $.258^{\star \star}$ \\
\hline Surface & & & & - & $-.259^{* * *}$ & $.099^{\text {ns }}$ & $.011^{\mathrm{ns}}$ & $.392^{* * *}$ & $-.172^{\star}$ & $-.354^{* * *}$ \\
\hline Intrinsic value & & & & & - & $.138^{\mathrm{ns}}$ & $.128^{\text {ns }}$ & $-.160^{\star}$ & $.230^{* *}$ & $.241^{* *}$ \\
\hline Personal/social & & & & & & - & $-.046^{\mathrm{ns}}$ & $-.040^{\text {ns }}$ & $-.004^{\text {ns }}$ & $-.121^{\mathrm{ns}}$ \\
\hline Career & & & & & & & - & $.154^{*}$ & $-.006^{n s}$ & $.103^{\mathrm{ns}}$ \\
\hline Lack of purpose & & & & & & & & - & $-.171^{*}$ & $-.164^{\star}$ \\
\hline Self-study (hours/week) & & & & & & & & & - & $.169^{*}$ \\
\hline Degree (\%) & & & & & & & & & & - \\
\hline
\end{tabular}

Table 2 Pearson correlation matrix $\left(n=179 ;{ }^{n s}\right.$ not significant, $\left.{ }^{*} p<.05,{ }^{* *} p<.01,{ }^{* *} p<.001\right)$ 


\begin{tabular}{|c|c|c|c|c|c|}
\hline \multirow[b]{2}{*}{$\begin{array}{l}\text { Perceived experiences of teaching and learning } \\
\text { (agree/disagree) and course demands (ease/difficulty) }\end{array}$} & \multicolumn{3}{|c|}{$\begin{array}{c}\text { Response profile } \\
\text { (frequency and percentage) }\end{array}$} & \multirow[b]{2}{*}{$\begin{array}{l}\text { Mean score } \\
\text { (SD) }\end{array}$} & \multirow[b]{2}{*}{$\begin{array}{l}\text { Cluster means } \\
\mathrm{C} 1-\mathrm{C}^{\dagger}\end{array}$} \\
\hline & $\begin{array}{l}\text { Positive } \\
\text { response }\end{array}$ & Neutral & $\begin{array}{l}\text { Negative } \\
\text { response }\end{array}$ & & \\
\hline Critical thinking (experience) & & & & $\begin{array}{c}4.11 \\
(0.624)\end{array}$ & $4.24-3.73^{n s}$ \\
\hline $\begin{array}{l}\text { To do well in this course you had to think critically about } \\
\text { the topics studied }\end{array}$ & $\begin{array}{c}168 \\
(93.9)\end{array}$ & $\begin{array}{c}9 \\
(5.0)\end{array}$ & $\begin{array}{c}2 \\
(1.1)\end{array}$ & $\begin{array}{c}4.32 \\
(0.801)\end{array}$ & $4.50-3.93$ \\
\hline $\begin{array}{l}\text { You had to really understand the subject to get good } \\
\text { marks on this course }\end{array}$ & $\begin{array}{c}142 \\
(79.3)\end{array}$ & $\begin{array}{c}22 \\
(12.3)\end{array}$ & $\begin{array}{l}15 \\
(8.4)\end{array}$ & $\begin{array}{c}3.90 \\
(0.624)\end{array}$ & $3.98-3.53$ \\
\hline Staff and student support (experience) & & & & $\begin{array}{c}4.02 \\
(0.530)\end{array}$ & $4.15-3.70^{n s}$ \\
\hline $\begin{array}{l}\text { Staff tried to share their enthusiasm about the subject } \\
\text { with us }\end{array}$ & $\begin{array}{c}168 \\
(93.9)\end{array}$ & $\begin{array}{c}8 \\
(4.5)\end{array}$ & $\begin{array}{c}3 \\
(1.7)\end{array}$ & $\begin{array}{c}4.23 \\
(0.607)\end{array}$ & $4.32-4.13$ \\
\hline $\begin{array}{l}\text { Students supported each other and tried to give help } \\
\text { when it was needed }\end{array}$ & $\begin{array}{c}130 \\
(72.6)\end{array}$ & $\begin{array}{c}32 \\
(17.9)\end{array}$ & $\begin{array}{c}17 \\
(9.5)\end{array}$ & $\begin{array}{c}3.80 \\
(0.875)\end{array}$ & $3.97-3.53$ \\
\hline Interest and enjoyment (experience) & & & & $\begin{array}{c}3.99 \\
(0.702)\end{array}$ & $4.32-3.03^{\star * *}$ \\
\hline I enjoyed being involved in this course & $\begin{array}{c}153 \\
(85.5)\end{array}$ & $\begin{array}{c}20 \\
(11.2)\end{array}$ & $\begin{array}{c}6 \\
(3.4)\end{array}$ & $\begin{array}{c}4.02 \\
(0.666)\end{array}$ & $4.32-3.27$ \\
\hline $\begin{array}{l}\text { I found most of what I learned in this course really } \\
\text { Interesting }\end{array}$ & $\begin{array}{l}147 \\
(82.1)\end{array}$ & $\begin{array}{c}18 \\
(10.1)\end{array}$ & $\begin{array}{c}14 \\
(7.9)\end{array}$ & $\begin{array}{c}3.96 \\
(0.813)\end{array}$ & $4.32-2.80$ \\
\hline Teaching for understanding (experience) & & & & $\begin{array}{c}3.85 \\
(0.558)\end{array}$ & $4.08-3.28^{\star * *}$ \\
\hline $\begin{array}{l}\text { This course encouraged me to relate what I learned to } \\
\text { issues in the wider world }\end{array}$ & $\begin{array}{c}143 \\
(79.9)\end{array}$ & $\begin{array}{c}24 \\
(13.4)\end{array}$ & $\begin{array}{c}12 \\
(6.7)\end{array}$ & $\begin{array}{c}3.97 \\
(0.820)\end{array}$ & $4.20-3.13$ \\
\hline $\begin{array}{l}\text { I was prompted to think about how well I was learning } \\
\text { and how I might improve }\end{array}$ & $\begin{array}{c}120 \\
(67.0)\end{array}$ & $\begin{array}{c}44 \\
(24.6)\end{array}$ & $\begin{array}{l}15 \\
(8.4)\end{array}$ & $\begin{array}{c}3.70 \\
(0.805)\end{array}$ & $3.97-3.33$ \\
\hline Aims and congruence (experience) & & & & $\begin{array}{c}3.84 \\
(0.567)\end{array}$ & $4.09-3.23^{\star \star \star}$ \\
\hline $\begin{array}{l}\text { It was clear to me what I was supposed to learn during } \\
\text { the course }\end{array}$ & $\begin{array}{c}149 \\
(83.2)\end{array}$ & $\begin{array}{c}22 \\
(12.3)\end{array}$ & $\begin{array}{c}8 \\
(4.5)\end{array}$ & $\begin{array}{l}3.98 \\
(0.703)\end{array}$ & $4.20-3.20$ \\
\hline $\begin{array}{l}\text { The topics seemed to follow each other in a way that } \\
\text { made sense to me }\end{array}$ & $\begin{array}{l}119 \\
(66.5)\end{array}$ & $\begin{array}{c}36 \\
(20.1)\end{array}$ & $\begin{array}{c}24 \\
(13.4)\end{array}$ & $\begin{array}{c}3.60 \\
(0.831)\end{array}$ & $3.98-3.20$ \\
\hline Set work and feedback (experience) & & & & 3.83 & $4.02-3.44^{\star \star}$ \\
\hline
\end{tabular}


It was clear to me what was expected in the work for this course

The feedback given on my set work helped to clarify

things I hadn't fully understood

\section{Choice allowed (experience)}

We were allowed some choice over what aspects of the subject to concentrate on

We were given a good deal of choice over how we went about learning

\section{Generic skills (demand)}

Using IT and computers

Tracking down information for myself

\section{Prior knowledge and pace (demand)}

What I was expected to know to begin with

The amount of work I was expected to do

\begin{tabular}{|c|c|c|c|c|}
\hline & & & (0.612) & \\
\hline $\begin{array}{c}148 \\
(82.7)\end{array}$ & $\begin{array}{c}23 \\
(12.8)\end{array}$ & $\begin{array}{c}8 \\
(4.5)\end{array}$ & $\begin{array}{c}3.99 \\
(0.742)\end{array}$ & $4.18-3.53$ \\
\hline \multirow[t]{2}{*}{$\begin{array}{c}115 \\
(64.2)\end{array}$} & $\begin{array}{c}44 \\
(24.6)\end{array}$ & $\begin{array}{c}20 \\
(11.2)\end{array}$ & $\begin{array}{c}3.65 \\
(0.870)\end{array}$ & $3.87-3.33$ \\
\hline & & & $\begin{array}{c}3.44 \\
(0.558)\end{array}$ & $3.69-3.20^{n s}$ \\
\hline \multirow{3}{*}{$\begin{array}{c}115 \\
(64.3) \\
98 \\
(54.7)\end{array}$} & $\begin{array}{c}34 \\
(19.0)\end{array}$ & $\begin{array}{c}30 \\
(16.7)\end{array}$ & $\begin{array}{c}3.54 \\
(0.973)\end{array}$ & $3.68-3.47$ \\
\hline & $\begin{array}{c}40 \\
(22.3)\end{array}$ & $\begin{array}{c}41 \\
(22.0)\end{array}$ & $\begin{array}{c}3.35 \\
(0.980)\end{array}$ & $3.70-2.93$ \\
\hline & & & $\begin{array}{c}3.66 \\
(0.631)\end{array}$ & $3.86-3.01^{\star * \star}$ \\
\hline $\begin{array}{c}143 \\
(79.9)\end{array}$ & $\begin{array}{c}11 \\
(6.1)\end{array}$ & $\begin{array}{c}25 \\
(14.0)\end{array}$ & $\begin{array}{c}3.86 \\
(1.004)\end{array}$ & $4.02-3.27$ \\
\hline $\begin{array}{c}109 \\
(60.9)\end{array}$ & $\begin{array}{c}28 \\
(15.6)\end{array}$ & $\begin{array}{c}42 \\
(23.4)\end{array}$ & $\begin{array}{c}3.44 \\
(0.960)\end{array}$ & $3.62-2.80$ \\
\hline & & & $\begin{array}{c}3.24 \\
(0.658)\end{array}$ & $3.29-3.09^{n s}$ \\
\hline $\begin{array}{c}92 \\
(51.4)\end{array}$ & $\begin{array}{c}57 \\
(31.8)\end{array}$ & $\begin{array}{c}30 \\
(16.8)\end{array}$ & $\begin{array}{c}3.49 \\
(0.829)\end{array}$ & $3.47-3.20$ \\
\hline $\begin{array}{c}49 \\
(27.4)\end{array}$ & $\begin{array}{c}48 \\
(26.8)\end{array}$ & $\begin{array}{c}82 \\
(45.8)\end{array}$ & $\begin{array}{c}2.79 \\
(1.015)\end{array}$ & $2.90-2.47$ \\
\hline
\end{tabular}

Table 3 Perceived experiences of teaching and learning and course demands showing highest and lowest scoring items $\left(\mathrm{n}=179\right.$; ${ }^{\text {Anova }}$ after adjustment) 


\begin{tabular}{|c|c|c|c|c|c|}
\hline \multirow[b]{2}{*}{ Method of course delivery } & \multicolumn{3}{|c|}{$\begin{array}{c}\text { Response profile } \\
\text { (frequency and percentage) }\end{array}$} & \multirow[b]{2}{*}{$\begin{array}{l}\text { Mean score } \\
\text { (SD) }\end{array}$} & \multirow[b]{2}{*}{$\begin{array}{c}\text { Cluster means } \\
\mathrm{C} 1-\mathrm{C}^{\dagger}\end{array}$} \\
\hline & $\begin{array}{l}\text { All/most of } \\
\text { the time }\end{array}$ & $\begin{array}{l}\text { About half of } \\
\text { the time }\end{array}$ & $\begin{array}{l}\text { Some of the } \\
\text { time /never }\end{array}$ & & \\
\hline Individual tutorials & $\begin{array}{c}126 \\
(70.4)\end{array}$ & $\begin{array}{c}32 \\
(17.9)\end{array}$ & $\begin{array}{c}21 \\
(11.7)\end{array}$ & $\begin{array}{c}3.86 \\
(0.987)\end{array}$ & $4.02-3.67^{\text {ns }}$ \\
\hline Specialised practical input & $\begin{array}{c}122 \\
(68.2)\end{array}$ & $\begin{array}{c}33 \\
(18.4)\end{array}$ & $\begin{array}{c}24 \\
(13.4)\end{array}$ & $\begin{array}{c}3.85 \\
(1.114)\end{array}$ & $4.08-3.40^{\mathrm{ns}}$ \\
\hline Group seminars & $\begin{array}{c}121 \\
(67.6)\end{array}$ & $\begin{array}{c}36 \\
(20.1)\end{array}$ & $\begin{array}{c}22 \\
(12.3)\end{array}$ & $\begin{array}{l}3.74 \\
(0.938)\end{array}$ & $3.98-3.47^{\mathrm{ns}}$ \\
\hline Interactive whole-year lectures & $\begin{array}{c}99 \\
(55.3)\end{array}$ & $\begin{array}{c}49 \\
(27.4)\end{array}$ & $\begin{array}{c}31 \\
(17.3)\end{array}$ & $\begin{array}{c}3.45 \\
(0.913)\end{array}$ & $3.73-2.80^{\star *}$ \\
\hline VLE online materials (Blackboard) & $\begin{array}{c}78 \\
(43.6)\end{array}$ & $\begin{array}{c}58 \\
(32.4)\end{array}$ & $\begin{array}{c}43 \\
(24.0)\end{array}$ & $\begin{array}{c}3.28 \\
(1.107)\end{array}$ & $3.72-2.47^{* \star *}$ \\
\hline Traditional whole-year lectures & $\begin{array}{c}74 \\
(41.3)\end{array}$ & $\begin{array}{c}57 \\
(31.8)\end{array}$ & $\begin{array}{c}48 \\
(26.8)\end{array}$ & $\begin{array}{l}3.15 \\
(0.949)\end{array}$ & $3.42-2.47^{\star *}$ \\
\hline
\end{tabular}

Table 4 Course interest and engagement ( $n=179$; ${ }^{\dagger}$ Anova after adjustment: ${ }^{n}$ not significant, ${ }^{*} p<.05,{ }^{* *} p<.01,{ }^{* * *} p<.001$ ) 


\begin{tabular}{|c|c|c|c|c|c|c|c|c|c|c|c|c|c|c|}
\hline & \multirow[b]{2}{*}{$\begin{array}{l}\text { BPS- } \\
\text { UKHE }\end{array}$} & \multirow[b]{2}{*}{ Deep } & \multirow[b]{2}{*}{$\begin{array}{c}\text { Organised } \\
\text { effort }\end{array}$} & \multirow[b]{2}{*}{ Surface } & \multicolumn{9}{|c|}{ Perceived experiences of teaching and learning (1-7) and course demands ( 8 and 9$)$} & \multirow[b]{2}{*}{$\begin{array}{c}\text { Degree } \\
(\%)\end{array}$} \\
\hline & & & & & 1 & 2 & 3 & 4 & 5 & 6 & 7 & 8 & 9 & \\
\hline BPS-UKHE & - & $-.421^{\star \star \star}$ & $-.527^{\star \star \star}$ & $.586^{* * *}$ & $-.463^{\star \star \star}$ & $-.256^{\star \star}$ & $-.402^{\star \star \star}$ & $-.312^{\star \star \star}$ & $-.217^{\star \star}$ & $-.246^{\star *}$ & $-.558^{\star \star \star}$ & $-.038^{\mathrm{ns}}$ & $-.281^{\star \star \star}$ & $-.318^{\star \star \star}$ \\
\hline Deep & & - & $.523^{\star \star *}$ & $-.281^{* \star *}$ & $.400^{* \star *}$ & $.023^{\text {ns }}$ & $.417^{* \star *}$ & $.361^{* * *}$ & $.296^{* * *}$ & $.239^{\star *}$ & $.328^{* * *}$ & $.168^{*}$ & $.273^{\star * *}$ & $.171^{*}$ \\
\hline Organised effort & & & - & $-.279^{\star \star \star}$ & $.329^{* *}$ & $.160^{*}$ & $.343^{\star \star \star}$ & $.282^{\star \star \star}$ & $.181^{*}$ & $.164^{*}$ & $.316^{\star \star \star}$ & $.062^{\text {ns }}$ & $.354^{\star \star *}$ & $.258^{\star *}$ \\
\hline 1. Aims and congruence & & & & & - & $.392^{\star \star \star}$ & $.491^{\star \star \star}$ & $.496^{\star * \star}$ & $.345^{\star \star \star}$ & $.326^{\star * *}$ & $.499^{\star \star \star}$ & $.201^{* *}$ & $.217^{\star \star}$ & $.086^{\mathrm{ns}}$ \\
\hline 2. Choice & & & & & & - & $.381^{* \star *}$ & $.219^{\star * *}$ & $.012^{\mathrm{ns}}$ & $.185^{*}$ & $.301^{* * *}$ & $.034^{\mathrm{ns}}$ & $.009^{n s}$ & $.010^{\mathrm{ns}}$ \\
\hline 3. Teaching for understanding & & & & & & & - & $.402^{\star * \star}$ & $.422^{\star \star \star}$ & $.353^{\star \star \star}$ & $.488^{\star * \star}$ & $.059^{\text {ns }}$ & $.174^{*}$ & $.133^{\text {ns }}$ \\
\hline 4. Set work and feedback & & & & & & & & - & $.322^{\star \star \star}$ & $.354^{\star \star \star}$ & $.329^{\star \star \star}$ & $.138^{*}$ & $.287^{\star \star \star}$ & $.150^{\star}$ \\
\hline 5. Critical thinking & & & & & & & & & - & $.152^{*}$ & $.260^{\star \star \star}$ & $-.048^{\text {ns }}$ & $.118^{\mathrm{ns}}$ & $.025^{\mathrm{ns}}$ \\
\hline 6. Staff and student support & & & & & & & & & & - & $.344^{* * *}$ & $.052^{\text {ns }}$ & $.223^{* *}$ & $.116^{\mathrm{ns}}$ \\
\hline 7. Interest and enjoyment & & & & & & & & & & & - & $.015^{\mathrm{ns}}$ & $.247^{\star \star \star}$ & $.162^{*}$ \\
\hline 8. Prior knowledge and pace & & & & & & & & & & & & - & $.426^{\star \star \star}$ & $-.050^{\text {ns }}$ \\
\hline 9. Generic skills & & & & & & & & & & & & & - & $.032^{\text {ns }}$ \\
\hline Degree (\%) & & & & & & & & & & & & & & - \\
\hline
\end{tabular}

Table 5 Pearson correlation matrix $\left(n=179 ;{ }^{n s}\right.$ not significant, $\left.{ }^{*} p<.05,{ }^{* *} p<.01,{ }^{* *} p<.001\right)$ 


\section{Student Characteristics}

Intelligence, personality and attitude

Feelings and emotions

Prior knowledge, experiences and outcomes

Orientation and commitment to learning

Perceptions of requirements

Influenced by teachers and mentors Interest and enjoyment

Subject-specific expertise

Beliefs, norms, values and expectations

Conceptions of knowledge and learning Approaches to learning

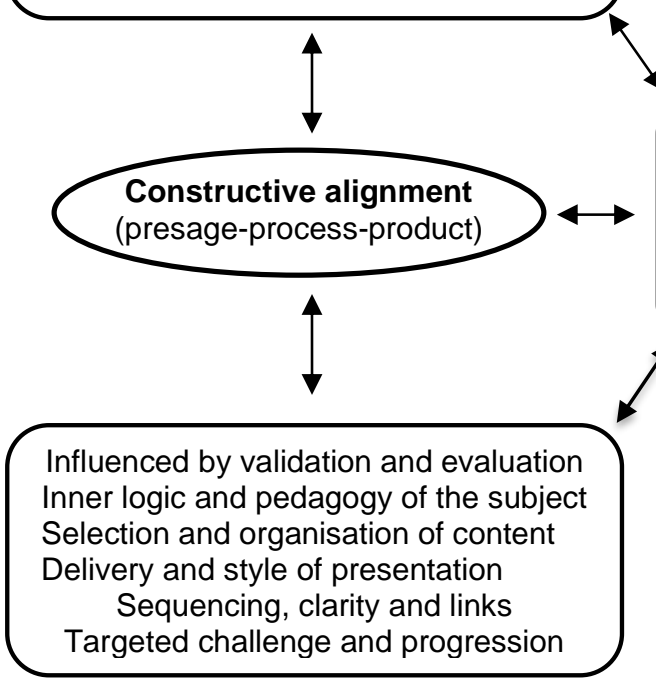

Quality of Meaningful Learning Knowledge and understanding

Critical and reflective thinking

Intellectual and transferable skills

General graduate attributes

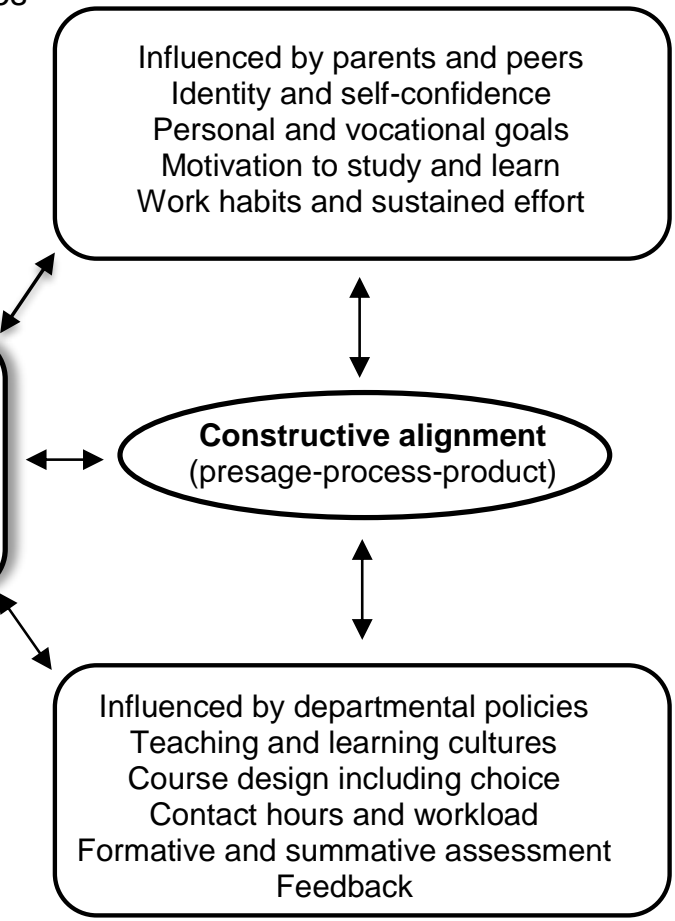

Scholarship of teaching and learning

Perceived role of the lecturer

Purpose of and being at university

Enthusiasm, empathy and support

Relationships

Beliefs, norms, values and expectations

\section{The Teaching and Learning Environment}

Figure 1 Heuristic model and conceptual framework of learning influences (after Entwistle 2008, 2009 and Biggs and Tang 2011) 


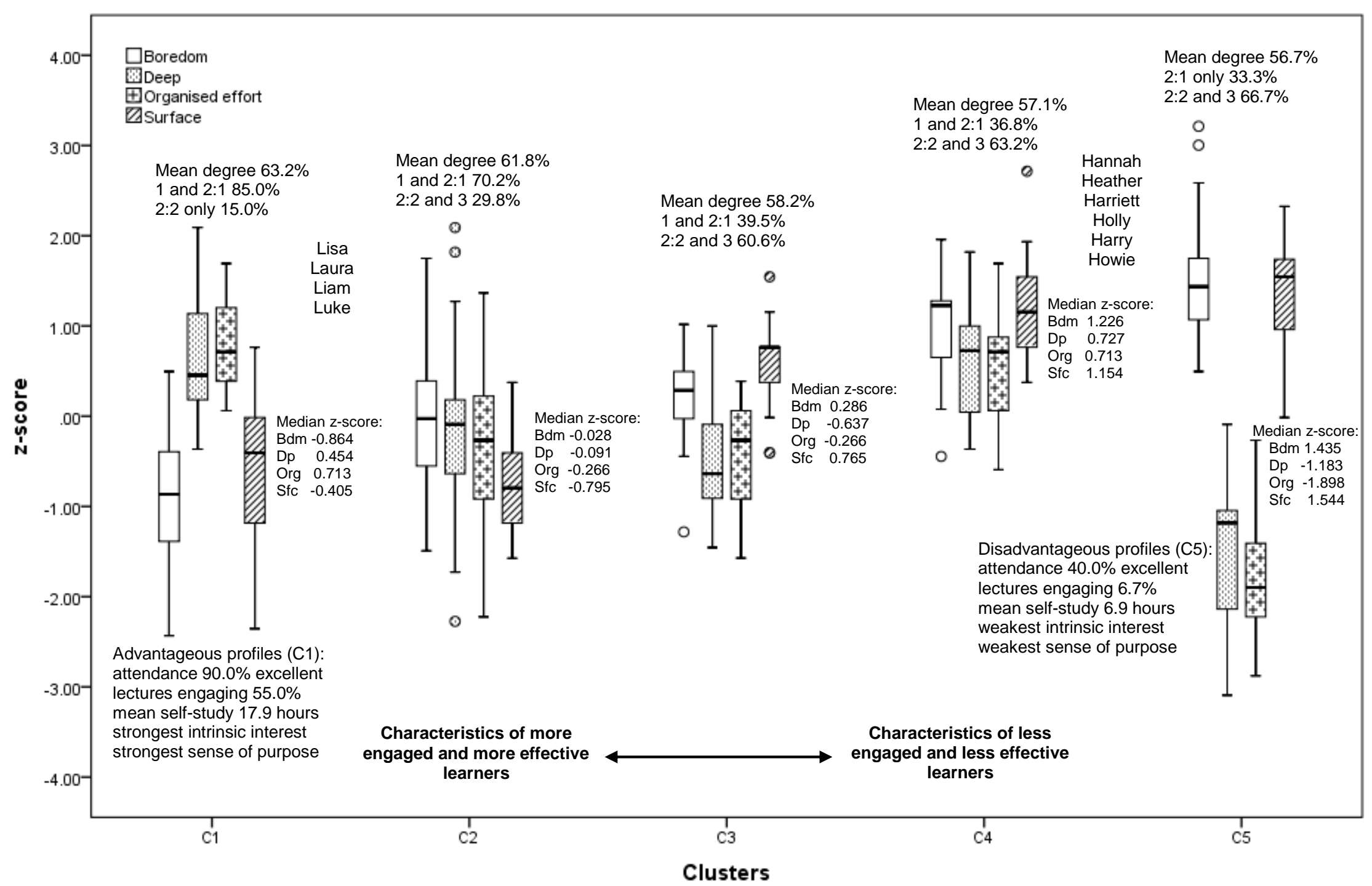

Figure 2 Relationship between academic trait boredom, ways of working, degree outcome and other variables in clusters $(n=179)$ 


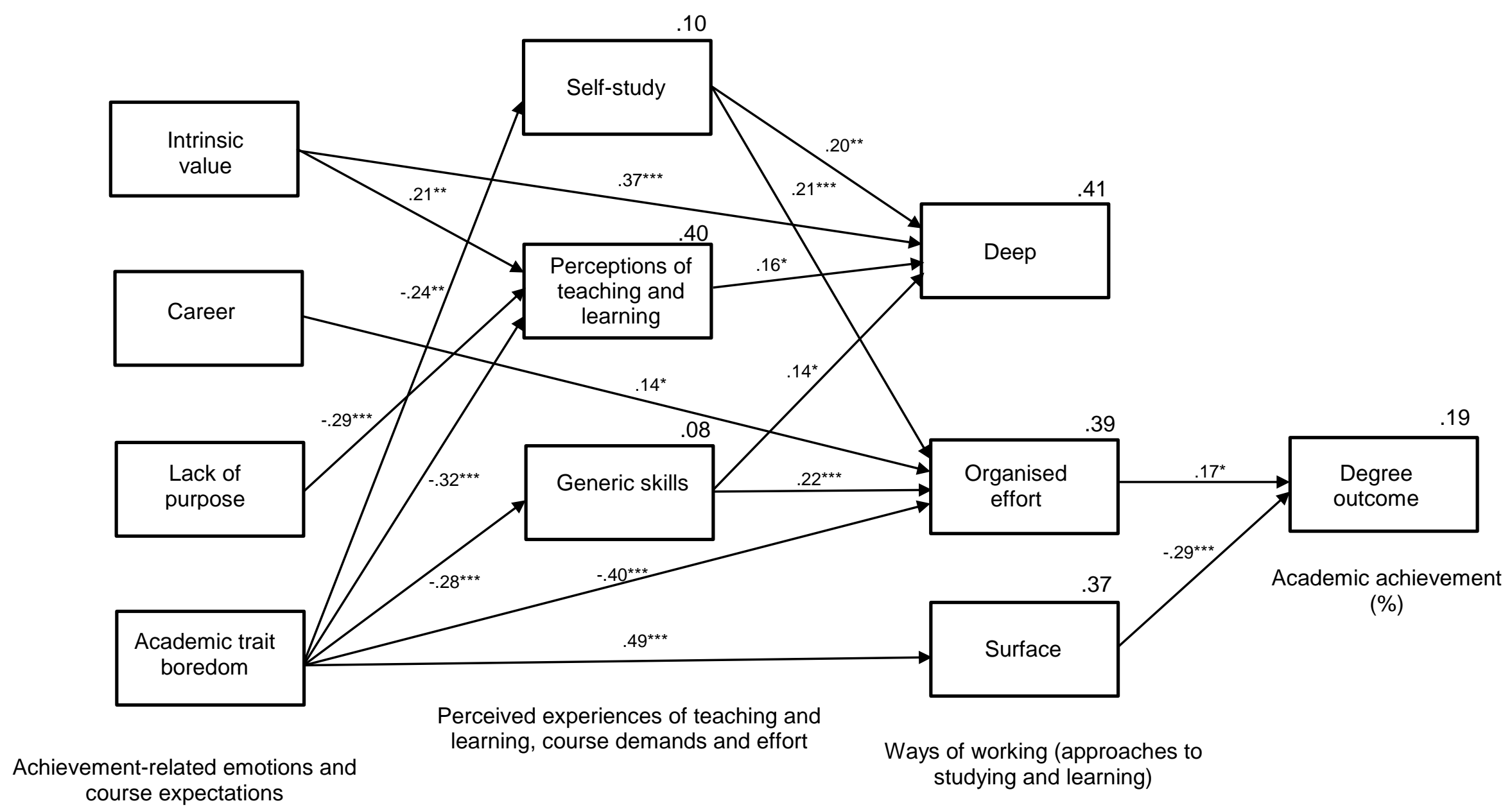

Figure 3 Simplified path diagram for observed variables $\left(n=179 ;{ }^{*} p<.05,{ }^{* *} p<.01,{ }^{* * *} p<.001\right)$ 